\title{
Acute Phase Proteins as Biomarkers in Animal Health and Welfare
}

\author{
Jaime Gómez-Laguna ${ }^{1}$, Francisco J. Salguero², \\ Francisco J. Pallarés ${ }^{3}$, Irene M. Rodríguez-Gómez ${ }^{4}$, \\ Inmaculada Barranco ${ }^{4}$ and Librado Carrasco ${ }^{4}$ \\ ${ }^{1}$ CICAP, Agri-food Research Centre, Pozoblanco, Córdoba \\ ${ }^{2}$ Veterinary Laboratories Agency, New Haw, Addlestone, Surrey \\ ${ }^{3}$ Department of Anatomy and Comparative Pathology, \\ Faculty of Veterinary Medicine, \\ Murcia University, Murcia \\ ${ }^{4}$ Department of Anatomy and Comparative Pathology, \\ Faculty of Veterinary Medicine, Córdoba University, \\ Córdoba \\ 1,3,4Spain \\ 2United Kingdom
}

\section{Introduction}

The acute phase proteins (APPs) are reactants synthesized during an acute phase response (APR) against several stimuli like infection, inflammation, stress, trauma or tissue damage (Petersen et al., 2004; Cerón et al., 2005). The main role of the APR is to restore the normal homeostasis of the organism after any of the stimuli mentioned above. In this sense, the APR is considered as part of the innate immune system triggering off functions just as leukocytosis, fever, chelation of serum zinc and iron, or opsonization (Cerón et al., 2005). During the APR organic concentrations of APPs may change, and measuring APPs levels is being used widely nowadays both in human and in veterinary medicine. The concentration of APPs may increase or decrease after an appropriate stimulus being classified as positive, moderate or negative APPs depending on the enhancement of its concentration. Thus, a positive APP may show up to 100-1000-fold increase in its serum concentration in 1-2 days; a moderate APP displays a 5 to 10-fold increase in 2-3 days; and a minor APP increase between $50 \%$ and $100 \%$. Negative APPs are those which decrease after a specific stimulus (Petersen et al., 2004; Cray et al., 2009; Eckersall \& Bell, 2010).

Serum samples are the most common sample used to measure the levels of APPs in both companion and farm animals. Recently, other specimens such as saliva or meat juice has been successfully used as samples for APPs measurements in dog (Parra et al., 2005) and pig (Gutiérrez et al., 2008; 2009). Saliva presents the advantage of being a non-invasive, easier and less stressful sampling method for the animals and meat juice represent a suitable alternative to serum or blood samples and simplifies the process of sampling collection at slaughter. 
In this sense, the extrahepatic synthesis of APPs is one of the recent subjects of study in the field of the APR. The synthesis of APPs is regulated by both endogenous glucocorticoids and the production of proinflammatory cytokines, mainly interleukin-1 (IL-1), IL-6 and tumor necrosis factor-alpha (TNF-a), which activate specific cells to synthesize APPs. The liver is the main target for the production of APPs, specially the hepatocytes; however, several extrahepatic sites have been reported. An extrahepatic synthesis of haptoglobin (Hp) has been reported in airway epithelial cells and immigrated leucocytes (Hiss et al., 2008) and extrahepatic production of C-reactive protein (CRP) has been observed in vascular smooth muscle cells (Kuji et al., 2007), pulmonary fibroblast and endothelial cells in the lung (Päiväniemi et al., 2009). In our group an extrahepatic expression of both Hp (Gutiérrez et al., 2011) and CRP (unpublished data) has been observed in epithelial cells from the respiratory tract, in the parotid salivary gland and in diaphragmatic myofibers from sick pigs (Fig. 1).

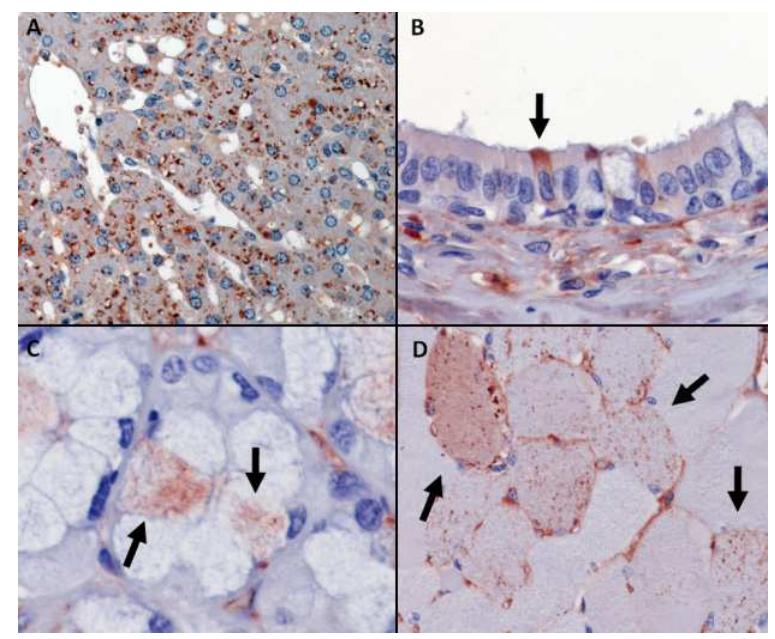

Fig. 1. Immunohistochemical haptoglobin expression in hepatocytes (1A), airway epithelial cells $(1 \mathrm{~B}$, arrow), epithelial glandular cells $(1 \mathrm{C}$, arrows), and diaphragmatic myofibers (1C, arrows).

Before describing the role of APPs in veterinary medicine, it should be useful to remind some of the functions of the main APPs. The main biological function of Hp consists on prevention of iron loss by the formation of haemoglobin-iron complexes (Ceciliani et al., 2002; Petersen et al., 2004). Therefore, Hp develops a bacteriostatic effect reducing the level of available iron for the microorganisms (Petersen et al., 2004). The expression of Hp has also been related to the secretion of anti-inflammatory cytokines, particularly IL-10, through the interaction with CD163, a haemoglobin scavenger receptor that is solely present in cells of monocyte/macrophage lineage (Moestrup \& Moller, 2004; Philippidis et al., 2004). However, the exact mechanism used by $\mathrm{Hp}$ as modulator of the immune response is not clear, acting as suppressor of lymphocyte proliferation in bovine (Murata \& Miyamoto, 1993), and as supporter of B and T lymphocytes proliferation and differentiation in Hpdeficient C57BL/6J mice (Huntoon et al., 2008).

Serum amyloid A (SAA) shows more than 100-fold increase after any injury, which triggers off the APR (Petersen et al., 2004). SAA carries out several functions related with the 
inflammatory response, just as cholesterol removal from the local site of inflammation and transport to hepatocytes; chemotaxis of monocytes, polymorphonuclear leukocytes and $\mathrm{T}$ cells; inhibitory effect on fever, oxidative burst, platelet activation and in vitro immune response (Ceciliani et al., 2002; Petersen et al., 2004). Secondary amyloidosis is triggered by a conformational change of SAA into an insoluble peptide, AA, which takes place when there is a marked high expression of SAA (Ceciliani et al., 2002).

$\mathrm{CRP}$ was first discovered in the serum of patients which suffered a pneumococcal infection, as a substance which reacted with $C$ polysaccharide (Petersen et al., 2004). In the acute phase response, CRP increases often more moderately than Hp or SAA, showing between 1 to 10 times increase (Petersen et al., 2004). Although some authors consider CRP as a useful tool to differentiate between a bacterial or a viral infection, other authors could not detect such differences because of the individual variability (Petersen et al., 2004). CRP participates in the innate immune response removing bacteria and damaged cells by complement activation and opsonisation, activating monocyte/macrophage to inflammatory cytokines production, and preventing neutrophils migration (Ceciliani et al., 2002; Petersen et al., 2004). Since CRP is a component of the innate response, it may be considered as an early bioindicator of health status in swine herds (Stevenson et al., 2006).

This chapter will deal with the role of APPs in domestic animal species, as well as their role in animal welfare, in disease and in the evaluation of prophylactic and therapeutic strategies.

\section{Useful acute phase proteins in domestic animal species}

As mentioned above, APPs are classified as positive, moderate, minor or negative depending on either the enhancement or the decrease in their serum concentration during the APR (Petersen et al., 2004; Cray et al., 2009; Eckersall \& Bell, 2010). The synthesis and role of APPs may differ depending on the animal species. In this sense, whereas an APP may act as a positive APP in one species, it may not suffer any change in other species, such as CRP in swine and in cattle, respectively (Table 1 ).

\begin{tabular}{lcccc}
\hline Species & Major APP & Moderate APP & Minor APP & Negative APP \\
\hline Dog & CRP, SAA & AGP, $\mathrm{Hp}, \mathrm{Cp}, \mathrm{Fb}$ & - & Albumin, Tf \\
Cat & AGP, SAA & $\mathrm{Hp}$ & - & Albumin, Tf \\
Horse & SAA & $\mathrm{Hp}, \mathrm{Fb}$ & - & Albumin \\
Swine & Pig-MAP, Hp, SAA & AGP, CRP & $\mathrm{Fb}$ & Albumin, Apo A-I \\
Cattle & Hp, SAA & AGP, MAP & $\mathrm{Fb}$ & Albumin \\
Sheep & Hp, SAA & AGP & $\mathrm{Fb}, \mathrm{Cp}$ & Albumin \\
Goat & $\mathrm{Hp}, \mathrm{SAA}$ & $\mathrm{Fb}, \mathrm{ASG}$ & $\mathrm{Cp}$ & Albumin \\
\hline
\end{tabular}

CRP: C-reactive protein; SAA: serum amyloid A; AGP: a $a_{1}$ acid glycoprotein; Hp: haptoglobin; Cp: ceruloplasmin; Fb: fibrinogen; Tf: transferrin; Pig-MAP: pig major acute phase protein; Apo A-I: apoliprotein A-I; MAP: major acute phase protein; ASG: acid soluble glycoprotein.

Table 1. Expression of APPs in different species according to their degree of importance.

It is well established that albumin participates as a negative APP in most of the animal species. On the other hand, $\mathrm{Hp}$ and fibrinogen $(\mathrm{Fb})$ are considered as positive APPs, although the enhancement shown by the former may be up to ten times higher than the one 
observed by the latter. CRP is a really useful biomarker in human for monitoring the course of different clinical processes, and its measure is also of interest in swine and dog. Nonetheless, the serum concentration of CRP does not suffer big changes in the APR in bovine or in cat. Therefore, the selection of the appropriate APP for each species is of key importance.

\subsection{APPs of significance in small animals}

The APR is mounted in a similar way both in dogs and cats; however they show few differences with respect to the behaviour of some APPs. Whereas Hp, SAA, and a $\mathrm{a}_{1}$-acid glycoprotein (AGP) are considered as positive APPs in both species, CRP acts as a positive APP in dogs but usually shows no changes in cats (Petersen et al., 2004; Cerón et al., 2005; Eckersall and Bell, 2010). In addition, Fb is a positive APP in dogs, but no information is available in cats (Petersen et al., 2004; Cerón et al., 2005). Finally, albumin participates as a negative APP in all mammalian species (Mackiewicz, 1997).

\subsubsection{Canine APPs}

In the dog the main APPs to consider are CRP and SAA, as positive APPs; AGP, Hp and ceruloplasmin (Cp), as moderate APPs; and albumin and transferrin, as negative APP (Petersen et al., 2004; Cerón et al., 2005) (Table 1). No age- or sex-related differences have been observed in the concentration of CRP for dogs (Yamamoto et al., 1994), however, adult dogs respond to inflammation with a higher enhancement in the concentration of both CRP and AGP than young animals do (Hayashi et al., 2001).

The concentration of APPs has been reported to rise after several bacterial, viral or parasitic infections, in autoimmune disorders and in neoplasia (just as lymphoma) (Table 2). In this sense, the magnitude of the increase of different APPs has been reported as a valuable tool to monitor parvoviral (Kocaturk et al., 2010) and Erlichia canis (Rikihisa et al., 1994) infections. Moreover, a correlation has been observed between the levels of APPs and the remission of the autoimmune hemolytic anemia (Mitchell et al., 2009). Some studies have been focused on the role of APPs in the monitoring of mammary tumors in the bitch but the results are contradictory. In these reports, the changes observed in the concentration of APPs have been related mainly to the inflammation associated to the tumor (Planellas et al., 2009; Tecles et al., 2009).

In the same way, it is interesting to take into account that the measure of APPs may not be of help in several processes. Nakamura et al. (2008) performed a study to determine the role of $\mathrm{CRP}$ in different diseases, concluding that the measure of CRP was not useful in neurological and endocrine processes.

\subsubsection{Feline APPs}

The APR has not been thoroughly studied in cats. However some relevant data are available in the literature. AGP and SAA act as positive APPs in the APR in cats, whereas Hp participates as a moderate APP and albumin and transferring as negative APPs (Petersen et al., 2004; Cerón et al., 2005; Paltrinieri, 2008) (Table 1). No age-related differences have been observed in the concentration of APPs in cats (Campbell et al., 2004).

Although scarce studies have been carried out to determine the role of APPs in feline species, there are several studies available concerning the role of APPs in feline infectious peritonitis (FIP) (Table 3). Thus, a persistent increase in the concentration of AGP, SAA and Hp has been reported in cats suffering from FIP (Giordano et al., 2004; Paltrinieri et al., 


\begin{tabular}{|c|c|c|c|}
\hline & Disorder & $\begin{array}{l}\text { Acute Phase } \\
\text { Protein }\end{array}$ & Reference \\
\hline Inflammation & $\begin{array}{l}\text { Acute pancreatitis } \\
\text { Pyometra } \\
\text { Polyarthritis } \\
\text { Inflammatory bowel disease } \\
\text { Rhinitis } \\
\text { Surgery }\end{array}$ & $\begin{array}{c}\text { CRP } \\
\text { CRP, Hp, SAA } \\
\text { CRP } \\
\text { CRP } \\
\text { CRP, Hp } \\
\text { CRP , Hp, Cp }\end{array}$ & $\begin{array}{l}\text { Nakamura et al., } 2008 \\
\text { Dabrowski et al., } 2009 \\
\text { Tvarijonaviciute et al., } 2011 \\
\text { Jergens at al., } 2003 \\
\text { Sheahan et al., } 2010 \\
\text { Serin \& Ulutas, } 2010\end{array}$ \\
\hline Bacteria & $\begin{array}{l}\text { Bordetella bronchiseptica } \\
\text { Escherichia coli } \\
\text { Staphylococcus aureus } \\
\text { Leptospira interrogans }\end{array}$ & $\begin{array}{c}\text { CRP } \\
\text { CRP, SAA, Hp } \\
\text { CRP, SAA, Hp } \\
\text { CRP, Hp }\end{array}$ & $\begin{array}{l}\text { Yamamoto et al., } 1994 \\
\text { Dabrowski et al., } 2009 \\
\text { Dabrowski et al., } 2009 \\
\text { Mastrorilli et al., } 2007\end{array}$ \\
\hline Viruses & Parvovirus & CRP, SAA, AGP & $\begin{array}{l}\text { Yule et al., } 1997 \\
\text { Kocaturk et al., } 2010\end{array}$ \\
\hline Parasites & $\begin{array}{l}\text { Babesiosis } \\
\text { Erlichia canis } \\
\text { Leishmania infantum } \\
\text { Trypanosomiasis } \\
\text { Granulocytic anaplasmosis }\end{array}$ & $\begin{array}{l}\text { CRP, SAA, AGP } \\
\text { CRP, AGP } \\
\text { CRP, Hp, Cp } \\
\text { CRP, Hp } \\
\text { CRP }\end{array}$ & $\begin{array}{l}\text { Lobetti et al., 2000; } \\
\text { Matjako et al., } 2007 \\
\text { Rikihisa et al., } 1994 \\
\text { Martínez-Subiela et al., } 2002 \\
\text { Ndung' u et al., } 1991 \\
\text { Pantchev, } 2010\end{array}$ \\
\hline Neoplasia & $\begin{array}{l}\text { Round cell tumor (lymphoma) } \\
\text { Carcinoma } \\
\text { Sarcoma }\end{array}$ & CRP, AGP & $\begin{array}{l}\text { Ogilvie et al., } 1993 \\
\text { Mischke et al., } 2007 \\
\text { Nakamura et al., } 2008 \\
\text { Yuki et al., } 2011\end{array}$ \\
\hline Endocrine & Cushing's syndrome & $\mathrm{Hp}, \mathrm{Fb}$ & Caldin et al., 2009 \\
\hline Autoimmune & $\begin{array}{l}\text { Autoimmune hemolytic } \\
\text { anemia } \\
\text { Rheumatoid arthritis }\end{array}$ & $\begin{array}{l}\text { CRP } \\
\text { Cp }\end{array}$ & $\begin{array}{l}\text { Caspi et al., } 1987 \\
\text { Tecles et al., } 2005\end{array}$ \\
\hline
\end{tabular}

CRP: C-reactive protein; Hp: haptoglobin; SAA: serum amyloid A; CP: ceruloplasmin; AGP: $\mathrm{a}_{1}$-acid glycoprotein.

Table 2. Main canine disorders and specific APPs that play a significant role in each disease (modified from Cerón et al., 2005).

2007b). Moreover, AGP has been shown to be useful in monitoring the early interferon (IFN) treatment of parvoviral infected cats (Paltrinieri et al., 2007a). SAA has been reported as a useful tool in the diagnosis, monitoring and treatment of feline pancreatitis (Tamamoto et al., 2009). An enhancement in the concentration of AGP and Hp has been observed in anemic cats suffering from pyothorax, abscesses or fat necrosis (Ottenjann et al., 2006). Some studies have been focused on the expression of APPs in cats with neoplasia, however, whereas some authors describe no changes in APPs concentration in cats with lymphoma (Correa et al., 2001) others show a significant increase of AGP or SAA in cats bearing carcinomas, sarcomas or round cell tumors (Selting et al., 2000; Tamamoto et al., 2008). 


\begin{tabular}{|c|c|c|c|}
\hline & Disorder & $\begin{array}{l}\text { Acute Phase } \\
\text { Protein }\end{array}$ & Reference \\
\hline Inflammation & Pancreatitis & SAA & Tamamoto et al., 2008, 2009 \\
\hline & Reactive amyloidosis & AGP, SAA, Hp & Kajikawa et al., 1999 \\
\hline & Renal failure, FLUTD 1 & SAA & Sasaki et al., 2003 \\
\hline & $\begin{array}{l}\text { Abscesses, pyothorax, fat } \\
\text { necrosis }\end{array}$ & $\mathrm{AGP}, \mathrm{Hp}$ & Ottenjann et al., 1996 \\
\hline & Lipopolysaccharide & AGP, SAA, Hp & Kajikawa et al., 1999 \\
\hline & Injury, liver disorders & SAA & Sasaki et al., 2003 \\
\hline & Surgery & AGP, SAA, Hp & Kajikawa et al., 1999 \\
\hline Bacteria & Chlamydophila psittaci & AGP & Terwee et al., 1998 \\
\hline Viruses & Feline infectious peritonitis & AGP, SAA, Hp & Duthie et al., 1997 \\
\hline & & & Giordano et al., 2004 \\
\hline & & & Paltrinieri et al., 2007b \\
\hline & Feline immunodeficiency & $\mathrm{AGP}, \mathrm{Hp}$ & Duthie et al., 1997 \\
\hline & Parvovirosis & AGP & Paltrinieri et al., 2007a \\
\hline & Feline calicivirus & AGP & Terwee et al., 1997 \\
\hline Neoplasia & Lymphoma & SAA, AGP & Selting et al., 2000 \\
\hline & Malignant mesothelioma & & Sasaki et al., 2003 \\
\hline & Carcinoma & & Tamamoto et al., 2008 \\
\hline & Sarcoma & & \\
\hline Endocrine & Hyperthyroidism & SAA & Sasaki et al., 2003 \\
\hline & Diabetes mellitus & & Tamamoto et al., 2008 \\
\hline Autoimmune & $\begin{array}{l}\text { Autoimmune hemolytic } \\
\text { anemia }\end{array}$ & SAA & Paltrinieri, 2007 \\
\hline & Polycystic disease & & Tamamoto et al., 2008 \\
\hline & Familial amyloidosis & & \\
\hline
\end{tabular}

${ }^{1}$ FLUTD: Feline Low Urinary Tract Disease; SAA: serum amyloid A; AGP: a1-acid glycoprotein; Hp: haptoglobin.

Table 3. Main APPs related with the diagnosis of feline disorders.

\subsection{APPs of significance in large animals}

In large animals, besides all the research carry out concerning the role of APPs in inflammatory and infectious disease, there is an intense ongoing investigation on the APR triggered off by the stress related to several conditions, such as transport, feeding or housing conditions. These studies are valuable in order to determine the animal welfare status of the herds in order to both improve the production and obtain products of higher quality.

\subsubsection{Equine APPs}

As in cats, there are just few studies concerning the role of APPs in horses. SAA is the main $\mathrm{APP}$ in equines participating in the APR as a major APP, whereas both $\mathrm{Hp}$ and $\mathrm{Fb}$ acts as moderate APPs. Similar to other mammalian species, albumin is considered as a negative APP (Cray et al., 2009; Eckersall \& Bell, 2010) (Table 1). Attention must be paid to the age were the concentration of APPs is going to be measured. Thus, in the first week of life of the foal there is a physiological enhancement in the level of SAA, as well as in the mare just after foaling (Nunokawa et al., 1993; Paltrinieri et al., 1998). In addition, an increase of SAA is observed after vaccination (Andersen et al., 2011). 


\begin{tabular}{llcl}
\hline \multicolumn{1}{c}{ Disorder } & Acute Phase Protein & \multicolumn{1}{c}{ Reference } \\
\hline Inflammation & Surgery & SAA, Fb & Jacobsen et al., 2009 \\
& Colic & SAA & Vandenplas et al., 2005 \\
& $\begin{array}{l}\text { Non-infectious arthritis } \\
\text { Infectious arthritis }\end{array}$ & SAA, Hp, Fb & Hultén et al., 2002 \\
& Laminitis & SAA & Jacobsen et al., 2006a; 2006b \\
& Equine dysautonomia & Hp & Petersen et al., 2004 \\
Bacteria & Escherichia coli & Hp, Cp & Milne et al., 1991 \\
& (endometritis) & SAA, Fb & Mette et al., 2010 \\
& $\begin{array}{l}\text { Streptococcus zooepidemicus } \\
\text { (bronchopneumonia) }\end{array}$ & SAA & Hobo et al., 2007 \\
& Septicemia & SAA & Paltrinieri et al., 2008 \\
Viruses & Equine Influenza & SAA & Hultén et al., 1999 \\
Stress & Training & Fb, Hp & Fazio et al., 2010 \\
Others & Early embrionary death & SAA, Hp & Krakowski et al., 2011 \\
& Vaccination & SAA, Fb & Andersen et al., 2011 \\
\hline
\end{tabular}

AGP: $a_{1}$-acid glycoprotein; SAA: serum amyloid A; Hp: haptoglobin.

Table 4. Equine disorders and specific APPs for their diagnosis and monitoring.

Changes in the concentration of SAA have been reported in horses in several conditions, just as non-septic arthritis, laminitis, colic, or influenza infection. Other conditions which may lead to an increase in the level of this and/or another APPs in horses are shown in Table 4.

However, there are several conditions in which the use of APPs is not completely justified. In foals it is controversial if the measure of SAA may be a useful tool for the diagnosis of bronchopneumonia associated to Rhodococcus equi (Hultén \& Demmers, 2002; Cohen et al., 2005). In addition, other plasmatic proteins, such as the plasma iron, have been reported to better reflect acute inflammation than do APPs (Borges et al., 2007). On the other hand, the levels of APPs are not affected by selenium dose or source (Calamari et al., 2010).

\subsubsection{Bovine APPs}

In bovines it is important to take into consideration that some APPs, just as CRP, are not useful tools to measure the APR. The major APPs in cattle are Hp and SAA, acting both AGP and major acute phase protein (MAP) as moderate APPs and $\mathrm{Fb}$ as a minor APP. Albumin participates in the APR as a negative responder (Petersen et al., 2004; Eckersall \& Bell, 2010) (Table 1).

There are several factors that may imply variations in the expression of APPs. In this sense, the breed of the animals has to be considered before carrying out an analysis since, for example, the Holsteins show a prolonged production of the AGP, which is only slightly elevated in the Sahiwals (Glass \& Jensen, 2007). In another study, differences with respect to the level of $\mathrm{Cp}$ in both calves and cows were observed between Angus and Romosinuano 
breeds in response to weaning and transportation (Qiu et al., 2007). Another factor to consider is the age of the animals, being increased the levels of the APPs at calving and reaching baseline values during the first 3 weeks of life (Orro et al., 2008).

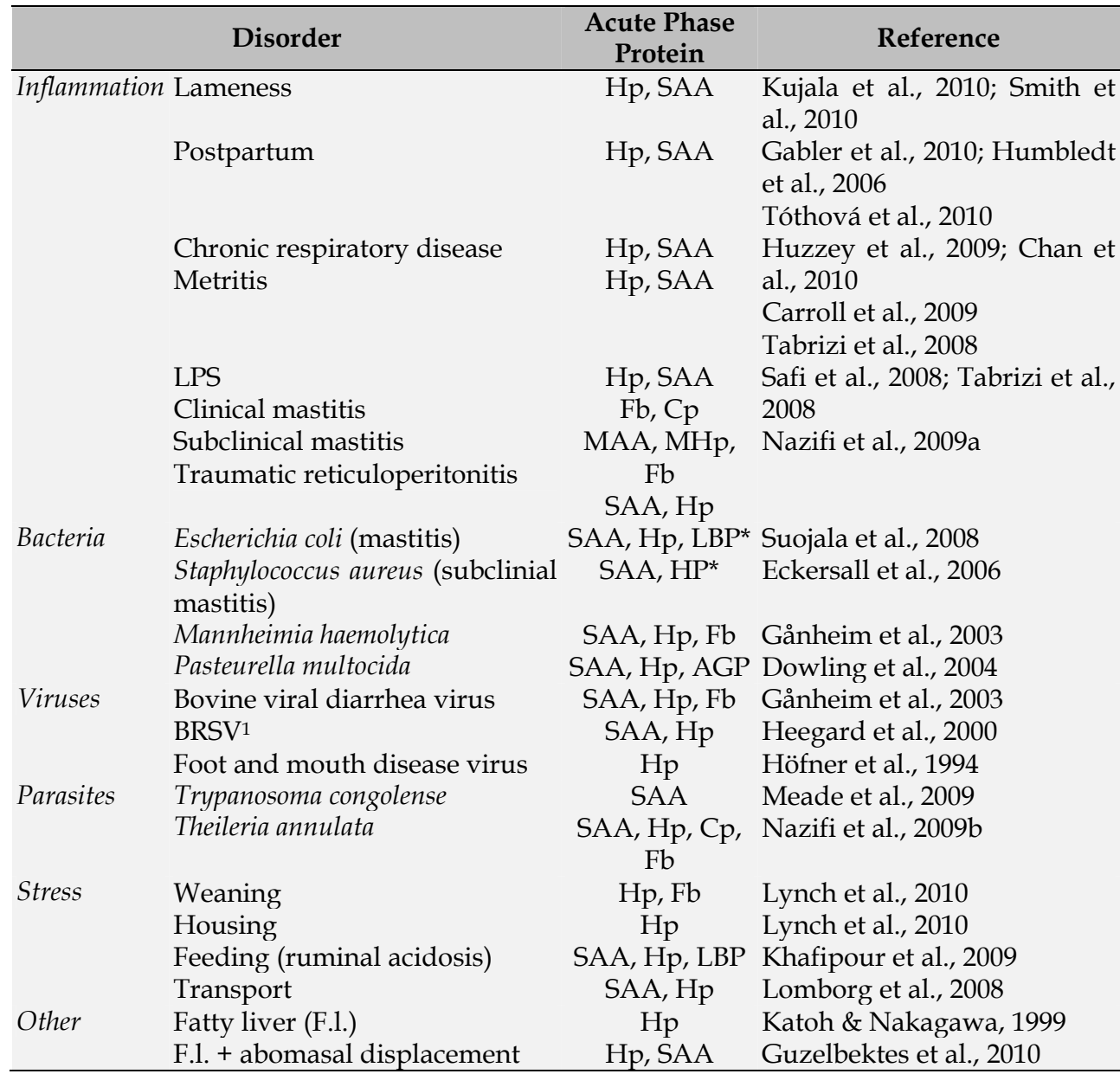

${ }^{1}$ BRSV: bovine respiratory syncytial virus; *All the three APPs increased both in milk and serum. Hp: haptoglobin; SAA: serum amyloid A; Cp: ceruloplasmin; Fb: fibrinogen; MAA: milk A amyloid; MHp: milk haptoglobin; LBP: lipopolysaccharide-binding protein; AGP: $a_{1}$-acid glycoprotein.

Table 5. Main APPs reported in different disorders in cattle useful for their diagnosis and/or monitoring.

Several studies are available concerning the role of APPs in different disorders affecting bovine species (Table 5). Many of them are focused on the APR in mastitis, being interesting the higher concentration of Hp and LBP response triggered off in mastitis caused by gram negative bacteria than in those caused by gram positive bacteria (Wen et al., 2010). Some of these studies determine the differences between the concentration of APPs in serum and in 
milk. As it could be expected in cases of mastitis, the concentration of APPs is much higher in milk than in serum (Tabrizi et al., 2008; Safi et al., 2009).

Other studies are also focused on the changes experimented by APPs against different stressors or metabolic conditions, such as hepatic lipidosis (fatty liver) (Table 5).

\subsubsection{APPs in small ruminants}

The APR in small ruminants is poorly described. The different APPs may play a similar role both in sheep and goat but some differences have been reported. Hp and SAA are considered as major APPs and $\mathrm{CP}$ as a minor APP in both ovine and caprine APRs. Nonetheless, Fb participates as a minor APP in sheep but as a moderate APP in goat. AGP and acid soluble glycoprotein (ASG) are also moderate APPs of the ovine and caprine APRs, respectively (Table 1 ). In both species the concentration of albumin diminishes after an appropriate stimulus (González et al., 2008; Cray et al., 2009).

Most of the studies performed on sheep are focused on the role of APPs after several inflammatory stimuli, being carried out few studies concerning specific bacterial, viral or parasitic infections (Table 6). Some studies are focused on the expression of APPs against lentiviral infections, being observed a local expression of SAA (Sack \& Zink, 1992) but no serum enhancement of $\mathrm{Hp}$ or $\mathrm{Fb}$ concentrations (de la Concha et al., 2000).

Few studies have been focused on the changes of APPs in milk secretions of sheep. Whereas SAA levels in milk may be useful for the diagnosis on subclinical mastitis in individual ewes further studies are needed to determine its usefulness from bulk milk (Winter et al., 2006). Interestingly, opposite to bovine, the changes in the concentration of SAA in ewes with mastitis experimentally induced by Staphylococcus epidermidis are observed earlier in serum than in milk (Winter et al., 2003).

In goats the studies are rather limited than in sheep. The measure of APPs has been shown to not imply any advantage against the traditional markers observed for the diagnosis of pregnancy toxemia (González et al., 2011). Moreover, an increase of several APPs has been observed in the Alpine ibex with sarcoptic mange (Rahmann et al., 2010), which probably would act in the same way in domestic goats.

\subsubsection{Porcine APPs}

In swine there is an extensive literature available concerning the usefulness of APPs as a tool for monitoring both the health status of a herd as well as its welfare conditions. In pigs there are three major APPs, namely Hp, SAA and pig-major acute phase protein (Pig-MAP), whereas CRP and AGP are considered as moderate APPs and Fb as a minor APP (Petersen et al., 2004; Cray et al., 2009). Gender differences have been reported in swine exposed to stressors, being observed significantly higher concentrations of CRP and Hp in females than in males, although males tend to have higher Pig-MAP concentrations (Piñeiro M et al., 2007).

As it has just been said, APPs have been tested in pigs after exposure to stress (Salamano et al., 2008) and after natural (Chen et al., 2003; Parra et al., 2006) or experimental infections (Francisco et al., 1996; Asai et al., 1999; Magnusson et al., 1999; Knura-Deszczk et al., 2002; Van Gucht et al., 2005; Stevenson et al., 2006). Increased levels of different APPs have been reported in porcine viral and bacterial infections. The most significant of them are summarized in Table 7. As occurred in other species, inflammation or bacterial diseases trend to trigger off a more marked APR with a higher increase in the concentration of APPs 


\begin{tabular}{|c|c|c|c|}
\hline & Disorders in ovine & $\begin{array}{c}\text { Acute Phase } \\
\text { Protein }\end{array}$ & Reference \\
\hline Inflammation & $\begin{array}{l}\text { Peptidoglycan-polysaccharide } \\
\text { Uterine involution } \\
\text { Pneumonia } \\
\text { Chronic pneumonia } \\
\text { Subclinical mastitis } \\
\text { Intrathoratic yeast inyection } \\
\text { Surgery } \\
\text { Castration }\end{array}$ & $\begin{array}{c}\text { Hp, SAA } \\
\text { Hp } \\
\text { Hp, Cp, Fb } \\
\text { SAA } \\
\text { SAA } \\
\mathrm{Hp}, \mathrm{Cp}, \mathrm{Fb} \\
\mathrm{Hp}, \mathrm{Cp}, \mathrm{Fb} \\
\text { Hp }\end{array}$ & $\begin{array}{c}\text { Dow et al ., } 2010 \\
\text { Regassa \& Noakes, } 1999 \\
\text { Pfeffer \& Rogers, } 1989 \\
\text { Kingston et al., } 1982 \\
\text { Winter et al., } 2006 \\
\text { Pfeffer et al., } 1993 \\
\text { Pfeffer \& Rogers, } 1989 \\
\text { Paull et al., 2009 }\end{array}$ \\
\hline Bacteria & $\begin{array}{l}\text { Corynebacterium } \\
\text { pseudotuberculosis } \\
\text { Mannheimia haemolytica } \\
\text { Staphylococcus epidermidis } \\
\text { (mastitis) }\end{array}$ & $\begin{array}{l}\text { Hp, SAA, AGP } \\
\text { Hp, SAA, CRP, Cp } \\
\text { SAA }\end{array}$ & $\begin{array}{c}\text { Pépin et al., 1991; } \\
\text { Eckersall et al., } 2007 \\
\text { Ulutas \& Ozpinar, } 2006 \\
\text { Winter et al., } 2003\end{array}$ \\
\hline Viruses & Lentivirus & SAA & Sack \& Zink, 1992 \\
\hline Parasites & Myasis & $\mathrm{SAA}, \mathrm{Hp}, \mathrm{Fb}$ & $\begin{array}{l}\text { Colditz et al., 2001; } \\
\text { O'meara et al., } 1995\end{array}$ \\
\hline Stress & Feeding & SAA & Eckersall et al., 2008 \\
\hline \multirow[t]{2}{*}{ Other } & $\begin{array}{l}\text { Mulesing } \\
\text { Carprofen + mulesing } \\
\text { NSAIDs + mulesing } \\
\text { Vaccination }\end{array}$ & $\begin{array}{c}\mathrm{Hp}, \mathrm{SAA}, \mathrm{Fb} \\
\mathrm{Hp} \\
\mathrm{Hp} \\
\mathrm{Hp}, \text { SAA }\end{array}$ & $\begin{array}{l}\text { Lepherd et al., } 2011 \\
\text { Colditz et al., } 2009 \\
\text { Paull et al., } 2008 \\
\text { Eckersall et al., } 2008 \\
\end{array}$ \\
\hline & Disorders in goats & $\begin{array}{c}\text { Acute Phase } \\
\text { Protein }\end{array}$ & Reference \\
\hline Inflammation & $\begin{array}{l}\text { Pregnancy toxemia } \\
\text { Turpentine oil }\end{array}$ & $\begin{array}{c}\mathrm{Hp} \\
\mathrm{Hp}, \mathrm{SAA}, \mathrm{ASG}, \mathrm{Fb}\end{array}$ & $\begin{array}{l}\text { González et al., } 2011 \\
\text { González et al., } 2008\end{array}$ \\
\hline Viruses & Lentivirus & SAA & Sack \& Zink, 1992 \\
\hline Parasites & $\begin{array}{l}\text { Sarcoptes scabiei } \\
\text { Trichuris spp. }+ \\
\text { Trichostrongylidae spp. }+ \text { Fasciola } \\
\text { spp. }\end{array}$ & $\begin{array}{l}\text { SAA, AGP, Hp, Cp } \\
\text { SAA, Hp }\end{array}$ & $\begin{array}{l}\text { Rahmann et al., } 2010 \\
\text { Ulutaş et al., } 2008\end{array}$ \\
\hline
\end{tabular}

Hp: haptoglobin; SAA: serum amyloid A; Cp: ceruloplasmin; Fb: fibrinogen; AGP: a1-acid glycoprotein; CRP: C-reactive protein; ASG: acid soluble glycoprotein.

Table 6. Main APPs reported in different disorders in small ruminants.

than viral infections, however, the infection with specific porcine viruses such as porcine circovirus type 2 induces an enhancement in APPs comparable to the one observed in inflammation or Mycoplasma hyopneumoniae infection (Parra et al., 2006).

Recently, an interesting paper regarding the role of APPs in the diagnosis of infectious diseases in pigs has been published. In this paper the authors demonstrate specific combinations of APPs which may help to the diagnosis of porcine infectious diseases better than the analysis of individual APPs (Heegard et al., 2011). 


\begin{tabular}{|c|c|c|c|}
\hline & Disorder & $\begin{array}{l}\text { Acute Phase } \\
\text { Protein }\end{array}$ & Reference \\
\hline \multirow[t]{2}{*}{ Inflammation } & Lipopolysaccharide & & Dritz et al., 1996 \\
\hline & Surgery & $\mathrm{CRP}, \mathrm{Hp}$ & $\begin{array}{l}\text { Hernandez-Richter et al., } \\
2001\end{array}$ \\
\hline \multirow[t]{8}{*}{ Bacteria } & Actinobacillus & & \\
\hline & pleuropneumoniae & SAA, CRP & Skovgaard et al., 2009 \\
\hline & Mycoplasma hyopneumoniae & Pig-MAP, Hp, CRP & Parra et al., 2006 \\
\hline & Streptococcus suis & SAA, CRP & Sorensen et al., 2009 \\
\hline & Bordetella bornchiseptica + & & Francisco et al., 1996 \\
\hline & Pasteurella multocida type D & Hp & Magnusson et al., 1999 \\
\hline & Mycoplasma hyorhinis & $\mathrm{Hp}$ & Jacobson et al., 2004 \\
\hline & Brachyspira hyodysenteriae & SAA, Hp & \\
\hline \multirow[t]{4}{*}{ Viruses } & PRRS1 & Pig-MAP, Hp & Gómez-Laguna et al., 2010a \\
\hline & $\mathrm{PCV}^{2}$ & Pig-MAP, Hp & Grau-Roma et al., 2009 \\
\hline & Influenza & $\mathrm{Hp}, \mathrm{CRP}$ & Barbé et al., 2011 \\
\hline & Aujeszky & $\mathrm{Hp}$ & Parra et al., 2006 \\
\hline Parasites & Toxoplasma gondii & $\mathrm{Hp}$ & Jungersen et al., 1999 \\
\hline \multirow[t]{3}{*}{ Stress } & Transportation & Pig-MAP, Hp & Piñeiro et al., 2007 \\
\hline & Housing & $\mathrm{Hp}, \mathrm{CRP}$ & Salamano et al., 2008 \\
\hline & Slaughter & $\begin{array}{l}\text { SAA, CRP, Pig- } \\
\text { MAP, Hp }\end{array}$ & Piñeiro M et al., 2007 \\
\hline Others & Gestation & $\mathrm{Fb}$ & Sorrels et al., 2007 \\
\hline
\end{tabular}

1PRRS: porcine reproductive and respiratory síndrome; ${ }^{2} \mathrm{PCV} 2$ : porcine circovirus type 2; CRP: Creactive protein; Hp: haptoglobin; SAA: serum amyloid A; Pig-MAP: pig-major acute phase protein; Fb: fibrinogen.

Table 7. Main conditions and APPs increased in the early response in pigs.

Although several studies are being conducted to determine the welfare status of several potential stressors in pigs, just as transportation, housing conditions, feeding or slaughter, a lack of an evident APR is reported in some investigations (Johnson et al., 2008; Weber et al., 2008). In the Table 7 appear some conditions which may evoke an increase in APPs.

\section{Acute phase proteins as biomarkers of animal welfare}

Stress is considered to be the most important factor to control on animal welfare. Hans Selye was the first author to introduce the concept of stress in 1936, as the non-specific response of the body to external challenges such as pathogens or a harsh physical environment (Selye, 1998). Nowadays in the animal production systems some aspects related to the housing and feeding system, changes in diet and transportation are considered as causes of stress, which compromise the welfare of animals (Broom \& Johnson, 1993). Also, stress causes a risk in the animal homeostasis which results in an inflammatory response leading to immunosupression. This immunosupression favors the appearance of diseases such as shipping fever of feedlot cattle and Glasser's disease in pigs. Additionally, poor welfare may conduct to losses in performance and meat quality. Recently, the population has a significant and increasing concern for animal welfare where consumers prefer to pay higher prices for those products whose quality is guaranteed. 
Animal welfare can be measured by different parameters such us mortality in the herd, presence of injuries, behavioral assessment, plasma glucocorticoid concentrations and heart rate (Broom \& Johnson, 1993). Nonetheless, a high number of measured factors should be done to establish a reliable evaluation (Grandin, 1997). Different studies have shown that APPs are a useful tool in the assessment of animal welfare (Eckersall, 2000; Murata et al., 2004). With the measure of APPs, a rapid diagnosis can be made before the behavioral signs appear, as a result an effective treatment can be performed in order to solve losses in performance.

Firstly, it is definitely important to know the baseline APPs concentrations in healthy animals just to establish the reference ranges for the proteins. Different studies (Heegaard et al., 1998; Petersen et al., 2002; Campbell et al., 2005; Carpintero et al., 2005; Martín et al., 2005; Clapperton et al., 2007; Piñeiro et al., 2007, 2009) have determined the baseline ranges of APPs in pigs, these results were summarized by Diack et al. (2011).

There is no agreement if the age of the animal can modify the baseline levels of APPs. Thus, Piñeiro $\mathrm{C}$ et al. (personal communication) pointed to not changes in APPs values, whereas Alsemgeest et al. (1993, 1995) and Orro et al. (2008) showed significant differences depending on the age in calves. Also, there were significant differences between genetic lines for CRP, Pig-MAP and transthyretin in pigs, the same finding was reported by Frank et al. (2005), Shutterland et al. (2006), and Clapperton et al. (2005, 2007). These results highlight that APPs concentrations should be adjusted for factors such as age, sex, genetic line or individual herds, being needed the determination of a reference range which allow a reliable use of APPs measurement. Even, it has been reported that the same stressor can cause differences among animals (Von Borell, 1995).

Recently, some authors have shown that it is more significant to study the correlation between two APPs than the changes of the level of only one APP following a stressful situation. In this sense, significant correlations have been found between $\mathrm{Hp}$ and CRP (Diack et al., 2011), between Hp and Pig-MAP (Clapperton et al., 2007; Diack et al., 2011) and between CRP and Pig-MAP (Diack et al., 2011) in pigs.

\subsection{APPs and welfare in small animals}

Dogs and cats also experience changes in their homeostasis due to stressors (Eckersall, 2000). Although it has not been reported any article about the behaviour of APPs in dogs and cats, cortisol levels have been reported to increase when dogs are introduced to novel kennels (Rooney et al., 2007) and where cats are maintained in non-enrichment shelter (McCobb et al., 2005). Knowing that APPs are sensitive biomarkers of welfare, it may be possible that an increase in APP concentration occurs after these conditions.

As a conclusion, not only transportation but also the stress of adapting to new environment comprising feeding, housing and different stock densities may cause an enhancement in APP concentration levels. Thus, the measure of APPs results in a useful parameter in order to assess animal's welfare, particularly in farm animals where the analysis of APPs could help to assess if the new automation machines are according to welfare conditions or in contrast are a cause of stress in animals and taking into account that a decrease in the APPs levels can express an adaptation to the stressful situation.

\subsection{APPs and welfare in large animals}

\subsubsection{Bovine APPs of importance in stress and welfare}

The majority of studies concerning to APPs performed in this species suffer from baseline ranges which allowed to compare the experimental results with the healthy situation. 
Indeed, the absence of some control animals in the experiments carried out in matter of transportation and mixing animals, does not allow having a clear understanding of the APP behaviour. However, it is important to highlight that SAA suggests being the better APP to determine changes in weaning, feeding and housing systems in cattle.

Conner et al. (1988) described the increase of APPs in response to stress stimuli in calves. Table 8 summarized the studies performed in different possible stressful situations in this species.

\begin{tabular}{|c|c|c|}
\hline Conditions & Acute Phase Proteins & Reference \\
\hline 3 hours transport after weaning & $\uparrow \mathrm{SAA}, \mathrm{Fb}, \mathrm{Cp}$ & $\begin{array}{l}\text { Arthington et al., } \\
2003\end{array}$ \\
\hline Road and sea transport & $\mathrm{NC} \mathrm{Hp}, \mathrm{Fb}$ & $\begin{array}{l}\text { Earley \& Murray, } \\
2010\end{array}$ \\
\hline Mixing animals & $\mathrm{NC} \mathrm{Fb}, \mathrm{Cp}, \mathrm{AGP}$ & $\begin{array}{l}\text { Arthington et al., } \\
2003\end{array}$ \\
\hline Dietary differences on diet & $\mathrm{NC} \mathrm{Hp}, \mathrm{Fb}, \mathrm{SAA}$ & Berry et al., 2004 \\
\hline Different housing and feeding systems & $\begin{array}{r}\uparrow \text { SAA } \\
\text { NC Hp }\end{array}$ & Saco et al., 2008 \\
\hline $\begin{array}{l}\text { Housing (different number of heifers } \\
\text { per concentrate feeding place) }\end{array}$ & $\uparrow \mathrm{Hp}$ & González et al., 2008 \\
\hline Housing (different types of floor) & $\begin{array}{r}\uparrow \mathrm{SAA} \\
\mathrm{NCHp}\end{array}$ & $\begin{array}{l}\text { Alsemgeest et al., } \\
1995\end{array}$ \\
\hline Parturition & $\uparrow$ SAA, Hp, AGP, LPS & Orro et al., 2008 \\
\hline
\end{tabular}

$\uparrow$ : increased expression; NC: no change in expression; SAA: serum amyloid A; Fb: fibrinogen; $\mathrm{Cp}$ : ceruloplasmin; Hp: haptoglobin; AGP: $\mathrm{a}_{1}$-acid glycoprotein; LPS: lipopolysaccharide.

Table 8. APPs levels depend on the studied stressor.

Regarding transportation, Arthington et al. (2003) showed changes in APPs levels, these changes were transient and not significantly altered. Also, the absence of a weaning control does not allow establishing a solid conclusion.

In cattle, it has been reported that competition for food can result in poor welfare and production losses (Miller \& Wood-Gush, 1991). The results showed that the energy level of the diet does not induce changes in APP concentrations. The genetics background has also proven to be important in cows, where SAA levels showed an increase in semi-feral cows in comparison with feed type selected breed.

SAA was the main protein enhanced depending on the housing system, this major APP in cattle may be a better biomarker of the health status.

The results found in bibliography about parturition are controversial. Nonetheless, concentrations of APPs were higher in those calves which needed the use of forceful extraction, so we conclude that parturition increases the levels of APPs.

\subsubsection{APPs of importance in small ruminants stress and welfare}

The number of studies about welfare and APPs in this species of animals is scarce. In ewes, it has been reported that sheep which were transported for 30 and 48 hours, exhibit greater 
total plasma protein concentrations than those transported for 12 hours. Hp and albumin were considered within the total plasma protein levels (Fisher et al., 2010). More studies should be performed in this topic in order to assess the use of APPs as biomarkers of welfare in sheep and goats.

\subsubsection{Porcine APPs of importance in stress and welfare}

Pigs belong to the species in which more studies have been carried out regarding animal welfare. In fact, there is a tight European Union Legislation which regulates the conditions of raising animals to assess the well-being.

\begin{tabular}{|c|c|c|}
\hline Condition & Acute Phase Proteins & Reference \\
\hline $\begin{array}{l}\text { Average time transport }(24 \mathrm{~h})+ \\
\text { poor transport conditions }\end{array}$ & $\uparrow$ Pig-MAP, Hp & $\begin{array}{c}\text { Saco et al., } 2003 \\
\text { Piñeiro M et al., } 2007\end{array}$ \\
\hline $\begin{array}{l}\text { Long time transport }(48 \mathrm{~h})+\text { great } \\
\text { transport conditions }\end{array}$ & $\uparrow$ Pig-MAP & $\begin{array}{c}\text { Saco et al., } 2003 \\
\text { Piñeiro M et al., } 2007\end{array}$ \\
\hline $\begin{array}{l}\text { Short time transport }(6-12 h)+ \\
\text { commercial conditions }\end{array}$ & $\begin{array}{c}\uparrow \text { Pig-MAP, Hp, CRP, SAA } \\
\downarrow \text { Apo A-I }\end{array}$ & $\begin{array}{c}\text { Saco et al., } 2003 \\
\text { Piñeiro M et al., } 2007\end{array}$ \\
\hline $\begin{array}{l}\text { Long time transport }+ \\
\text { management and new } \\
\text { accommodation }\end{array}$ & $\uparrow$ Pig-MAP, Hp, CRP & Salamano et al., 2008 \\
\hline Changes in pattern of food & $\begin{array}{c}\uparrow \text { Pig-MAP, Hp, CRP } \\
\text { (males) } \\
\downarrow \text { Apo A-I (males) }\end{array}$ & Piñeiro C et al., 2007 \\
\hline Organic versus conventional food & NC Hp & Millet et al., 2005 \\
\hline Housing (gestation crates) & $\mathrm{NC} \mathrm{Hp}, \mathrm{Fb}, \mathrm{AGP}$ & Sorrels et al., 2007 \\
\hline Group versus cages & NC Pig-MAP & $\begin{array}{l}\text { Rodríguez-Gómez et al., } \\
\text { (unpublished data) }\end{array}$ \\
\hline $\begin{array}{l}\text { Organic versus conventional } \\
\text { housing }\end{array}$ & $\uparrow \mathrm{Hp}$ & Millet et al., 2005 \\
\hline Different stock densities housing & $\begin{array}{c}\uparrow \text { Pig-MAP } \\
\text { NC Hp, CRP, Apo A-I }\end{array}$ & Marco-Ramell et al., 2011 \\
\hline
\end{tabular}

$\uparrow$ : increased expression; $\downarrow$ : decrease expression; NC: no change in expression; Pig-Map: pig-major acute phase protein; Hp: haptoglobin; CRP: C-reactive protein; SAA: serum amyloid A; Apo A-I: apoliprotein A-I; Fb: fibrinogen; AGP: $\alpha_{1}$-acid glycoprotein.

Table 9. APPs changes depend on the stressful condition studied.

Different studies have shown that shipment of animals can result in an APP response related to the stress of transportation. Stress in transportation can affect meat quality and as 
a result, the value of the commercial product (Warris, 1998, 2003). Table 9 summarizes the different studies performed according to the stressful condition studied. In general, APP levels are extremely sensitive to shipment in pigs. Although all major APPs experience changes in their levels, the variation in Pig-MAP and Hp concentrations were constant in the different situations. Apoliprotein A-I (Apo A-I), as a negative APP, was a good biomarker too (Saco et al., 2003; Piñeiro M et al., 2007). APP levels not only were increased after the trip but also as a result of the adaptation to the unfamiliar accommodation, handling procedures and mixing of the animals (Salamano et al., 2008).

The appearance of gastric ulcer is related to stress conditions such as poor management and changes in feeding. This damage leads to huge economical losses in porcine industry. In one study, feeding changes were transient and only in males, possibly due to a higher manifestation of behavior, where the fight, dominance and competition for the food between males are more evident than in females (Piñeiro $C$ et al., 2007). Also, the implementation of organic food did not show any advantage with respect to conventional food (Millet et al., 2005).

Other controversial topic which is in constant study is the type of gestation crates used during gestation in pigs. It is well-known that stress related to gestation can result in weird behaviour to the offspring and disturbances in the immune response leading to higher susceptibility to diseases (Eicher \& Burton, 2005). In the majority of the studies performed, no changes were found in APP levels. Only $\mathrm{Hp}$ and Pig-MAP proteins altered their concentrations as a result of changes in housing or stock densities housing, respectively. It should be expected that changes between organic versus conventional housing are more patent due to the intention to reproduce natural conditions. However, these results should be interpreted carefully due to some important stressors were not taken into account.

In summary, Pig-MAP and Hp should be considered the best biomarkers of welfare in pig production due to that their analysis can reflect a stressful situation.

\section{Disease and acute phase proteins}

The discovery of new biomarkers which allow the clinical monitoring of different diseases is nowadays encouraged in order to improve the treatment and therapeutics in each phase of the disease. Therefore, the use of APPs in diagnosis and their application in monitoring of treatments is considered as one of the most interesting applications of these proteins. In this sense, APPs have been widely used in human medicine as biomarkers of inflammation, infection or trauma; however, their use in veterinary medicine is more recent. Thus, a significant progress has been made in the detection, measurement and application of APPs as biomarkers in both companion and farm animals over recent years.

The monitoring of two or more APPs is highly valuable in different diseases as each APP may display a different kinetic after the infection or trauma in the animal (Eckersall, 2000). This information may be of interest to evaluate the progress of the disease and may help in the prognosis of the animal or herd health.

\subsection{Disease and APPs in small animals}

\subsubsection{Disease and APPs in dogs}

CRP, SAA, Hp and/or AGP are the main APPs in dogs which may show changes after different infectious diseases, inflammation or other disorders, just as neoplasia (Table 2). For example, an increase of CRP has been observed in parvovirus infection, and in this disease 
the magnitude of the increase in APPs could be a useful indicator of the prognosis, being CRP a potent predictor of mortality due to this process (Kocaturk et al., 2010).

High levels of CRP have been related to the onset of sepsis in several disease models in dogs. Thus, the marked increased of CRP reported in dogs infected by canine parvovirus type 2 were due to the appearance of sepsis in these animals (Kocaturk et al., 2010). In fact, the levels reported in this study were similar to those observed previously in dogs with septic processes (Caldin et al., 2009), and deal with the knowledge that usually bacterial infections elicit a much higher APR than viral infections do (Gruys et al., 2005). However, in the previous study (Kocaturk et al., 2010) the use of CRP was evaluated as diagnostic tool for differentiation of survivors versus non survivors displaying a high sensitivity (91\%) but a low specificity (61\%). For these reasons, the role of CRP as useful marker of sepsis in dogs although indicative of a septic disease remains still controversial.

Serum levels of SAA have been used in the monitoring of responses to treatments as hyperadrenocorticism treatment (Arteaga et al., 2010) or possible complications in postoperative periods as after surgery because of pyometra (Dabrowski et al., 2009). Due to the particular sensitivity of $\mathrm{Hp}$ to effects of corticoid in the dog, elevated concentrations of $\mathrm{Hp}$ are found after corticosteroids treatments or in cases of hyperadrenocorticism so this protein could be used as a method of screening for canine hyperadrenocorticism but not in monitoring of inflammation because of steroid treatments could interfere with results interpretation (Arteaga et al., 2010; Eckersall \& Bell 2010).

In dogs with a fracture or subjected to percutaneous gastrostomy, serum CRP and AGP levels correlated with the condition of the dogs and may be useful in routine testing for inflammation, in preclinical studies and in veterinary clinical biochemistry (Hayashi et al., 2001).

Changes in CRP and Hp have been reported in dogs with lymphatic neoplasia (Mischke et al., 2007). Dogs with mammary neoplasia have high CRP, SAA and Hp levels but the increased concentrations of APPs could be stimulated by different factors, such as metastasis, large size of the primary mass and ulceration or secondary inflammation of the neoplasm (Planellas et al., 2009; Tecles et al., 2009). Serum levels of these APPs are of use in the diagnosis and management of steroid responsive meningitis-arteritis (SRMA), particularly in relation to identifying relapse (Lowrie et al., 2009). Dog with gastric mucosa injury present elevated serum CRP, SAA and Hp levels and may be potentially useful together with gastroscopy in the diagnosis and monitoring of gastric injury (Bayramli \& Ulutas, 2008).

\subsubsection{Disease and APPs in felines}

Feline serum SAA, AGP and/or Hp levels increase in infectious diseases, such as feline infectious peritonitis (FIP), and others inflammatory conditions (Table 3). The serum concentration of SAA may be also a useful marker for evaluating response to treatment and disease exacerbation in feline pancreatitis (Tamamoto et al., 2009).

Elevated concentrations of AGP have been also found in serum of cats with lymphoma although did not provide useful information regarding response or survival of affected animals (Correa et al., 2001).

Increased levels of Hp have been seen in cats affected by FIP (Giordano et al., 2004). In cats experimentally inoculated with feline infectious peritonitis virus Hp levels increased very early and then slight decreased, but two weeks after experimental induction of the disease increased concentrations were found again (Stodddart et al 1988). Besides Hp, increased 
levels of AGP have also been reported in cats suffering from FIP, as it has been mentioned above. AGP may trigger several functions related with the regulation of the immune response. In this sense, the sialic acid content has been associated to the defensive functions proposed for AGP, favoring the competition of AGP for cell surface receptors, blocking the binding and the invasion of infectious agents (Ceciliani et al., 2004). Interestingly, it has been postulated that the enhancement in AGP concentrations observed in FIP may play a significant role in the immunopathogenesis of the disease. As stated before, AGP and its glycosylation pattern are associated with resistance or susceptibility to some viral diseases (Rabehi et al 1995). Furthermore, a hyposialylitation of feline AGP has been reported in cats with FIP (Ceciliani et al 2004). Following these results, Paltrinieri et al. (2007c) hypothesized that cats with endemic FCoV infection respond to increased viral burden by increasing the production of AGP and only cats with hyposialylated AGP have persistently increased AGP levels and develop FIP.

\subsection{Disease and APPs in large animals \\ 4.2.1 Disease and APPs in equines}

The measurement of APPs has potential use in the study of inflammatory disorders in equine medicine (Crisman et al., 2008). Increased serum concentrations of SAA have been found in horses affected by arthritis and a local synthesis of this protein has also been reported in the inflamed joint (Jacobsen et al., 2006a). Synovial fluid SAA concentration seems to be a good marker of infectious arthritis and present advantages as ease and speed of measurement and the fact that concentrations in synovial fluid were not influenced by repeated arthrocentesis in healthy horses (Jacobsen et al., 2006b). High levels of SAA in serum and an increased expression in endometrium have been reported in mares with experimentally induced endometritis (Mette et al., 2010). The serum concentration of SAA has demonstrated its utility for identification of the clinical condition of horses with bacterial pneumonia (Hobo et al., 2007). Horses with enteritis or colitis and conditions characterized by chronic inflammation (e.g. abdominal abscesses, peritonitis, or rectal tears) had SAA concentrations significantly greater than those for horses with other conditions so evaluation of SAA concentrations may be of use in identifying horses with colic attributable to diseases that have inflammation as a primary component of pathogenesis (Vandenplas et al., 2005).

In foals, increased concentrations of SAA have been found in septicaemic animals (Paltrinieri et al., 2008) and has been observed that foals with a strong suspicion of sepsis have significantly higher concentrations of SAA than compromised foals with noninfectious inflammatory disease (Duggan, 2008). The measurement of SAA could be a useful tool in the early diagnosis of neonatal septicaemia (Paltrinieri et al., 2008).

Surgical trauma produces an acute phase response and elective and non-elective surgery induces an increase in the serum levels of SAA (Pollock et al., 2005). The concentration of SAA have shown to reflect the intensity of the surgical trauma and may be useful for comparing surgical trauma associated with novel versus well-established surgical techniques (Jacobsen et al., 2009).

Elevated serum Hp levels have been reported in processes such as experimental aseptic arthritis, experimental local aseptic inflammation, experimentally induced noninfectious laminitis, grass sickness (equine dysautonomia) or castration (Petersen et al., 2004) (Table 4). 


\subsubsection{Disease and APPs in cattle}

In ruminants, the acute phase response is different from other species since $\mathrm{Hp}$ is considered as a major APP (Eckersall \& Bell 2010). Hp serum levels have been found increased in several inflammatory diseases such as endometritis, pneumonia, enteritis, peritonitis, mastitis and endocarditis (Murata et al., 2004; Petersen et al., 2004) (Table 5). In the case of metritis Hp values may assist in the early detection of the disease, providing increased opportunities for early treatment and prevention (Huzzey et al., 2009). Lameness due to claw disorders can be associated with a systemic acute phase response and elevated serum $\mathrm{Hp}$ in dairy cattle and the values of this protein can be used for monitoring the effectiveness of different treatments (Smith et al., 2010). In lame cows as a result of hoof disease increased concentrations of serum SAA were found while Hp values did not increased significantly what could mean that a greater stimulation associated with inflammation is needed for serum haptoglobin to increase (Kujala et al., 2010).

The serum values of SAA seem to be more sensitive marker for acute inflammation than Hp values (Horadagoda et al., 1999). In calves with chronic respiratory diseases elevated concentrations of $\mathrm{Hp}$ and SAA were found, and were significantly higher in dead or euthanized calves compared with calves in improved health status during therapy, so their evaluation could be useful in the determination of prognosis of the respiratory disease (Tóthová et al., 2010). In the case of viral pneumonias, the concentration of both proteins are elevated but the magnitude and duration of the Hp response was found to correlate well with the severity of clinical signs (fever) and with the extent of lung consolidation while SAA responded most rapidly to infection, so this last protein seems to be a more sensitive marker for viral pneumonia (Heegaard et al., 2000). In experimental infection with Mannheimia haemolytica, SAA was found to be more rapidly induced than Hp (Horadagoda et al.,1994), but in field cases, Hp produce a bigger and more prolonged response giving rise to its higher sensitivity in detecting disease (Angen et al., 2009).

The serum concentrations of Hp and SAA are increased in cases of mastitis (Gerardi et al., 2009; Petersen et al., 2004; Safi et al., 2009). In animals suffering from this disorder, the levels of these proteins have been also measured in milk. Hp levels in milk in cows affected by clinical mastitis were higher in cows with moderate to severe versus mild systemic disease (Wenz et al., 2010). In a study carried out by Safi et al. (2009) in Holstein cows from 7 different dairy farms the levels of $\mathrm{Hp}$ and amyloid A were measured in milk (AAM) and serum in order to evaluate the use and compare the accuracy of both APPs in these specimens for the diagnosis of subclinical mastitis based on bacterial culture results and with comparison with the California mastitis test (CMT) and somatic cell counts (SCC). The results of the study showed that the bacteria most found in the cases of subclinical mastitis were Streptococcus agalactiae and Staphylococcus aureus and the most accurate test for the diagnosis was AAM followed by CMT, SCC, HP in milk, SAA in serum and Hp in serum. Therefore test on milk generally were more accurate than test in serum in the diagnosis of subclinical mastitis. In another study carried out by Gerardi et al. (2009) about the use of SAA and AAM for the diagnosis of subclinical mastitis, the levels of AAM measured with a milk ELISA kit were significantly different between cows with subclinical and clinical mastitis and resulted to be a better tool for distinguishing subclinical from clinical mastitis than AAM measured with a serum ELISA kit. The results of this study also showed that the measurement of AAM could allow the identification of subclinical mastitis in equal or higher measure than SCC so the control of AAM and SAA on dairy farms could reduce both the laboratory costs and the time required for milk analysis. 
Serum levels of Hp and SAA have been measured in cows with left displaced abomasum, right displaced abomasum or abomasal volvulus and the values were most strongly associated with liver fat percentage than with the alteration in abomasums so an increase in SAA or Hp may indicate the presence of hepatic lipidosis in cattle with abomasal displacement (Guzelbektes et al., 2010)

AGP is considered as moderate APP in cow. Elevated serum levels of this protein have been reported in cows with respiratory disease (Nikunen et al., 2007). In experimental infections with Pasteurella multocida increases in the concentrations of AGP have been found to be more gradual and to remain elevated for longer than those observed for SAA or Hp (Dowling et al., 2002). Elevated serum levels of AGP have been also reported in animals with mastitis (Eckersall et al., 2001).

CRP serum levels have shown their utility as a marker or tool for evaluating the health status of a herd and could also be considered as useful criteria to assess the stress levels as well as in early surveillance of disease conditions in a dairy herd (Lee et al., 2003).

Another utility of APPs could be the assessment of animal health and welfare as an aid to meat inspections (Eckersall \& Bell, 2010). Hp and SAA serum concentrations al slaughter have been found increased in cows with infectious and metabolic diseases compared to animal with minor lesions and animal with acute lesions compared with healthy animals (Hirvonen et al., 1997; Tourlomousis et al., 2004).

\subsubsection{Disease and APPs in small ruminants}

In goats, $\mathrm{Hp}$ and SAA can be considered as major APPs, while ASG and Fb can be considered as moderate (Table 1). Increase in Hp, SAA, ASG, and Fb serum concentrations have been found after inducing an inflammatory response by subcutaneous injection of turpentine oil (González et al., 2008). Elevated serum levels of Hp have been reported in experimentally induced pregnancy toxemia in goats (González et al., 2011) (Table 6).

In sheep, serum Hp seems to be useful as a marker for the presence of bacterial infection (Skinner \& Roberts, 1994). Serum Hp, SAA and AGP were increased in an experimental model of caseous lymphadenitis, suggesting the results that AGP could have a role as a marker for chronic conditions in sheep (Eckersall et al., 2007). Increased serum CRP, Hp, Cp and $\mathrm{Fb}$ levels have been reported in animals infected with M. haemolytica (Ulutas \& Ozpinar, 2006) (Table 6).

\subsubsection{Disease and APPs in swine}

Increased serum levels of APPs have been reported in pigs experimentally and naturally infected with different virus and bacteria. Hp, CRP, SAA and Pig-MAP increased serum levels have been recently reported in pigs experimentally infected with porcine reproductive and respiratory syndrome virus (PRRSV) by our research group (Gómez-Laguna et al., $2010 \mathrm{~b}$ ). In this study we found an increase at 10 days post inoculation (dpi) in the serum levels of Hp and Pig-MAP. The serum levels of CRP and SAA showed a delayed increase at $17 \mathrm{dpi}$, being this last APP which reached the highest increase. The increase in the serum concentrations of $\mathrm{Hp}$ coincided with the highest titer of viraemia and a light enhancement in the levels of IL- 6 and TNF- $\alpha$, and might be related with and increased expression of IL-10. CRP participates in the complement activation and opsonization, and induces cytokine production by macrophages, whereas SAA is chemotactic for monocytes, $\mathrm{T}$ cells and polymorphonuclear, so the delayed increased expression found in both APPs may 
contribute to the establishment of an impaired non-efficient host-immune response. The result of our study suggested a modulation of the immune response by the enhanced expression of $\mathrm{Hp}$, and the poor or/and delayed expression of TNF- $\alpha$, CRP and SAA making feasible a prolonged viraemia and an inefficient PRRSV clearance. Another study carried out by our research group showed that the values of Hp and CRP in saliva and meat juice showed a similar kinetic than in serum in PRRSV-infected animals, so these samples could serve as complementary or alternative biomarkers in this disease (Gómez-Laguna et al., 2010a). The serum levels of these proteins are also increased in swine influenza virus (SIV) experimentally infected animals (Barbé et al., 2011). In pigs experimentally infected with classical swine fever and African swine fever viruses the serum concentrations of Hp, CRP and SAA were increased, being the levels of this last protein what more increase presented in the animals infected by both viruses (Sánchez-Cordón et al., 2007).

In animals naturally infected by PRRSV serum levels of Hp, CRP and SAA were found increased but not Pig-MAP concentrations. This APPs did not present any change when compared with Specific Pathogen Free (SPF) pigs taken as controls. In animals affected with Aujeszky's disease virus (ADV) only Hp showed increased levels, whereas pigs with porcine circovirus type 2 (PCV2) showed marked modifications in all APPs tested. The increases in the concentrations of APPs were higher in animals with clinical signs and concurrent bacterial processes (Parra et al., 2006). In a study in farms with animals clinically affected by Postweaning Multisystemic Wasting Syndrome (PMWS) caused by PCV2, the serum levels of $\mathrm{Hp}$ and Pig-MAP correlate with PCV2 viremia and the clinical course of the disease, concluding that Pig-MAP, in the conditions of this study, was better indicator of the PMWS status than Hp (Grau-Roma et al., 2009). In another study in farms affected by PMWS the increase in the viral load did not induce any SAA response (Wallgren et al., 2009).

In pigs experimentally infected by Streptococcus suis showed increased serum concentrations of Hp, CRP, SAA and Pig-MAP (Sorensen et al., 2006). In an experimental infection with Actinobacillus pleuropneumoniae increased serum levels of CRP and SAA were found but extrahepatic expression of these two proteins and of Hp and Pig-MAP was also detected in peripheral lymphoid tissues by PCR (Skovgaard et al., 2009). Extrahepatic presence of Hp has been also detected in lung by immunohistochemistry (Hiss et al., 2008). In field cases of enzootic pneumonia (EP) caused by Mycoplasma hyopneumoniae elevated serum levels of Hp, CRP, SAA and Pig-MAP have been reported (Parra et al., 2006) (Table 7).

In slaughter-aged pigs, the serum levels of Pig-MAP resulted to be more sensitive marker than $\mathrm{Hp}$ to differentiate animals suffering of pleuritis and cranio-ventral pulmonary consolidations (Saco et al., 2010). In a study carried out at slaughter by our research group serum levels of $\mathrm{Hp}$ and CRP in apparently healthy pigs were significantly higher in animals with lesions than those without lesions. In this same study was found that the extent and severity of lung lesions were related to serum levels of Hp (Pallarés et al., 2008). In another study the findings indicative of lesions compatible with enzootic pneumonia were associated with increased serum Hp at slaughter (Amory et al., 2004). In pigs with carcass condemnations due to abscesses increased serum APPs have been also reported (Heinonen et al., 2010). The use of APPs in finishing pigs just before sacrifice could provide information to the veterinary inspector about the possible appearance of lesions in these pigs and could serve as a tool to the meat industry to differentiate pigs with different health status that probably will match with different quality of carcasses (Pallarés et al., 2008). 


\section{Conclusion: APP in the evaluation of prophylaxis and therapeutic strategies}

APPs may act as biomarkers of inflammation allowing us to study the progression of the inflammatory response which is evoked during the acute phase of several diseases. The application of different therapeutic agents should diminish the intensity and the length of the inflammation and, therefore, the APR. Monitoring diseases and their treatments by means of APPs, may allow us to determine the efficiency and efficacy of a specific treatment. In this sense, Arteaga et al. (2010) monitored the response of canine hyperadrenocorticism to trilostane, and concluded that whereas only $\mathrm{Hp}$ (together with cholesterol and alkaline phosphatase) give some information about the control of the disease, no information was obtained from SAA or CRP, despite the former also decreased after the treatment. On the other hand, CRP represents an interesting parameter to measure in other processes, just as in canine lymphoma, where a significant decrease in CRP values was associated to remission after treatment with specific cytotoxic drugs (Nielsen et al., 2007). Specific APPs have been reported as value tools in monitoring both infectious diseases, just as CRP and Cp (but not SAA or Hp) in leishmaniasis (Martínez-Subiela et al., 2003) or CRP (but not Hp) in trypanosomiasis (N'dungu et al., 1991), and inflammatory processes, just as SAA in feline acute pancreatitis (associated with remission and recurrence) (Tamamoto et al., 2009) or Hp in bovine respiratory disease (Carter et al., 2002). In other conditions, just as canine hemolytic anemia, the changes in APPs were not useful to monitor the success of specific treatments (Griebsch et al., 2009; Mitchell et al., 2009).

On the other side, some prophylactic strategies are carried out in order to prevent the disease. One of the most common prophylactic strategies is the use of vaccines, which may prepare the organism to fight against a specific pathogen. Some vaccines are made with peptidic fragments from the microorganism or with the whole microorganism inactivated by different methods. Thus, vaccines may develop also an APR which may have an adverse effect and limit the efficacy and safety of these prophylactic strategies (Gruys et al., 2005). For these reasons, APPs may be used to determine the usefulness of vaccines as prophylactic agents, determining the magnitude of the inflammatory response evoked by their use. Moreover, aminoacids are required for the production of APPs, specifically phenylalanine, tryptophan and tyrosine may be detected in high percentage in some positive APPs. Therefore, vaccination may limit in some cases the recovery of the diseased animal acting opposite to the anabolism of the muscle (Gruys et al., 2005).

The inflammatory and the acute phase responses have been measured in cattle vaccinated with different clostridial vaccine candidates, being observed a higher expression of $\mathrm{Hp}$ and a decrease in feed consumption when a multiple clostridial- instead of a mono-clostridial vaccine was used, which points to the potential negative effects of multiple clostridialvaccinations (Stokka et al., 1994). Moreover, the utility of Hp values have been shown in the follow-up of the trimming and antibiotic treatment against several claw disorders (Smith et al., 2000).

In pigs, monitoring the APPs has been widely used to determine the usefulness of specific vaccines against both bacteria and viruses. A panel of APPs (Pig-MAP, Hp, CRP and Apo AI) has been used in order to monitor pigs challenge against both the bacteria Hameophilus parasuis and commercial and non-commercial bacterins finding a lower expression of APPs in vaccinated animals together with a shorter course of the disease and higher survival rates (Martín de la Fuente et al., 2010). Apo A-I and Pig-Map has been shown to be useful tools to 
monitor vaccination against Aujeszky's disease, showing the vaccinated animals none or only mild clinical signs, a less pronounced APR and recovered earlier to normal values (Carpintero et al., 2007). Nonetheless, further studies are required in order to assess the predictive value of APPs in vaccine testing.

Although a wide range of studies have been carried out to determine the role of APPs in several conditions just as stress, inflammation, infection or vaccination there is still necessity for establishing reference values which allow interpreting the results from the different studies and disorders. Some of this information may be available for some species of domestic animal; however, there is no still a global consensus to accept specific ranges for each APP in each species, as well as, validation of specific analytical techniques which enable the interlaboratory comparison of results.

\section{Acknowledgements}

This work was supported financially by the Spanish Ministry of Education and Science, project number AGL2009-12438/GAN.

\section{References}

Alsemgeest, S.P.; Lambooy, I.E., Wierenga, H.K., Dieleman, S.J., Meerkerk, B., van Edern A.M., Niewold, T.A. (1995). Influence of physical stress on the plasma concentration of erum amyloid-A (SAA) and haptoglobin (Hp) in calves. The Veterinary Quarterly Vol. 17, No. 1, pp. 9-12, ISSN 0165-2176

Alsemgeest, S.P.M., Taverne, M.A.M., Boosman, R., van der Weyden, G.C., Gruys, E., 1993. Peripartum acute-phase protein serum amyloid-A concentration in plasma of cows and fetuses. American Journal of Veterinary Research Vol. 54, pp. 164-167, ISSN 08916640

Alsemgeest, S.P.M.; Jonker, F.H., Taverne, M.A.M., Kalsbeek, H.C., Wensing, Th., Gruys, E., 1995. Serum amyloid-A (SAA) and haptoglobin (HP) plasma concentrations in newborn calves. Theriogenology Vol. 43, pp. 381-387, ISSN 0093-691X

Amory, J.R.; Mackenzie, A.M.,. Eckersall, P.D., Stear, M.J. \& Pearce, G.P. (2007). Influence of rearing conditions and respiratory disease on haptoglobin levels in the pig at slaughter. Research in Veterinary Science Vol. 83, No. 3, (December 2007), pp. 428435, ISSN 0034-5288

Andersen, S.A.; Petersen, H.H., Ersbøll, A.K., Falk-Rønne, J. \& Jacobsen, S. (2011). Vaccination elicits a prominent acute phase response in horses. The Veterinary Journal, doi:10.1016/j.tvjl.2011.01.019, ISSN 1090-0233

Angen, O.; Thomsen, J., Larsen, L.E., Larsen, J., Kokotovic, B., Heegaard, P.M. \& Enemark, J.M. (2009). Respiratory disease in calves: microbiological investigations on transtracheally aspirated bronchoalveolar fluid and acute phase protein response. Veterinary Microbiology Vol. 137, No. 1-2, (May 2009), pp. 165-171, ISSN 0378-1135

Arteaga, A., Dhand, N.K., McCann, T., Knottenbelt, C.M., Tebb, A.J., Evans, H., Eckersall, P.D. \& Ramsey IK. (2010). Monitoring the response of canine hyperadrenocorticism to trilostane treatment by assessment of acute phase protein concentrations. Journal of Small Animal Practice Vol. 51, No. 4, (April), pp. 204-209, ISSN 1748-5827

Arthington, J.D., Eicher, S.D., Kunkle, W.E., Marin, F.G. (2003). Effect of transportation and commingling on the acute-phase protein response, growth, and feed intake of 
newly waned beef calves. Journal of Animal Science Vol. 81, No. 5, (May 2003), pp.1120-1125, ISSN 0021-8812

Asai, T.; Mori, M., Okada, M., Uruno, K., Yazawa, S. \& Shibata, I. (1999). Elevated serum haptoglobin in pigs infected with porcine reproductive and respiratory syndrome virus. Veterinary Immunology and Immunopathology Vol. 70, No 1-2, pp. 143-148, ISSN 0165-2427

Barbé, F.; Atanasova, K. \& Van Reeth, K. (2011). Cytokines and acute phase proteins associated with acute swine influenza infection in pigs. The Veterinary Journal, Vol. 187, No. 1, (January 2011), pp. 48-53, ISSN 1090-0233

Bayramli, G. \& Ulutas, B. (2008). Acute phase protein response in dogs with experimentally induced gastric mucosal injury. Veterinary Clinical Pathology, Vol. 37, No. 3, (September 2008), pp. 312-316, ISSN 0275-6382

Berry, B.A., Confer, A.W., Krehbiel, C.R., Gill, D.R., Smith, R.A., Montelongo, M., (2004). Effects of dietary energy and starch concentrations for newly received feedlot calves: II. Acute-phase protein response. Journal of Animal Science, Vol. 82, No. 3 (March 2004), pp. 845-850, ISSN 0021-8812

Borges, A.S.; Divers, T.J., Stokol, T. \& Mohammed, O.H. (2007). Serum iron and plasma fibrinogen concentrations as indicators of systemic inflammatory diseases in horses. Journal of Veterinary Internal Medicine Vol. 21, No 3, (May-June 2007), pp. 489-494, ISSN 0891-6640

Broom, D.M. \& Johnson, K.G. (1993). Stress and Animal Welfare. In: Animal Behaviour Series. Chapman and Hall, ISBN 0813816599, London

Calamari, L.; Abeni, F. \& Bertin, G. (2010). Metabolic and hematological profiles in mature horses supplemented with different selenium sources and doses. Journal of Animal Science Vol. 88, No. 2, (February 2010), pp. 650-659, ISSN 1523-3163

Caldin, M.; Tasca, S., Carli, E., Bianchini, S., Furlanello, T., Martinez-Subiela, S. \& Cerón, J.J. (2009). Serum acute phase protein concentrations in dogs with hyperadrenocorticism with and without concurrent inflammatory conditions. Veterinary Clinical Pathology Vol. 38, No. 1, (March 2009), pp. 63-68, ISSN 0275-6382

Campbell, D.J., Rawlings, J.M., Koelsch, S., Wallace, J., Strain, J.J. \& Hannigan, B.M. (2004). Age-related differences in parameters of feline immune status. Veterinary Immunology and Immunopathology Vol. 100, No. 1-2, (July 2004), pp. 73-80, ISSN 0165-2427

Campbell, F.M., Waterston, M., Andresen, L.O., Sorensen, N.S., Heegaard, P.M., Eckersall, P.D. (2005). The negative acute phase response of serum transthyretin following Streptococcus suis infection in the pig. Veterinary Research Vol. 36, No. 4, (JulyAugust 2005), pp. 657-664, ISSN 0928-4249

Carpintero, R., Piñeiro, M., Andrés, M., Iturralde, M., Alava, M.A., Heegaard, P., Jobert, J.L., Madec, F., Lampreave, F. (2005). The concentration of apolipoprotein A-I decreases during experimentally induced acute processes in pigs. Infection and Immunity Vol. 73, No. 5, (May 2005), pp. 3184-3187, ISSN 1098-5522

Carpintero, R.; Alonso, C., Piñeiro, M., Iturralde, M., Andrés, M., Le Potier, M.F., Madec, F., Alava, M.A., Piñeiro, A. \& Lampreave, F. (2007). Pig major acute-phase protein and apolipoprotein A-I responses correlate with the clinical course of experimentally induced African Swine Fever and Aujeszky's disease. Veterinary Research Vol. 38, No. 5, (September-October 2007), pp. 741-753, ISSN 0891-6640 
Carter, J.N.; Meredith, G.L., Montelongo, M., Gill, D.R., Krehbiel, C.R., Payton, M.E. \& Confer, A.W. (2002). Relationship of vitamin E supplementation and antimicrobial treatment with acute-phase protein responses in cattle affected by naturally acquired respiratory tract disease. American Journal of Veterinary Research Vol. 63, No. 8, (August 2002), pp. 1111-1117, ISSN 0891-6640

Caspi, D.; Snel, F.W., Batt, R.M., Bennett, D., Rutteman, G.R., Hartman, E.G., Baltz, M.L., Gruys, E. \& Pepys, M.B. (1987). C-reactive protein in dogs. American Journal of Veterinary Research Vol. 48, No. 6, (June 1987), pp. 919-921, ISSN 0891-6640

Ceciliani, F.; Giordano, A. \& Spagnolo, V. (2002). The systemic reaction during inflammation: the acute-phase proteins. Protein and peptide letters Vol.9, No.3, (June 2002), pp.211-223, ISSN: 0929-8665

Ceciliani, F.; Grossi, C., Giordano, A., Pocacqua, V. \& Paltrinieri, S. (2004). Decreased sialylation of the acute phase protein alpha1-acid glycoprotein in feline infectious peritonitis (FIP). Veterinary Immunology and Immunopathology Vol. 99, No. 3-4, (June 2004), pp. 229-236, ISSN 0165-2427

Cerón, J.J.; Eckersall, P.D. \& Martínez-Subiela, S. (2005). Acute phase proteins in dogs and cats: current knowledge and future perspectives. Veterinary Clinical Pathology, Vol. 34, No. 2, (June 2005), pp. 85-99, ISSN 0275-6382

Chan, J.P., Chang, C.C., Hsu, W.L., Liu, W.B. \& Chen, T.H. (2010). Association of increased serum acute-phase protein concentrations with reproductive performance in dairy cows with postpartum metritis. Veterinary Clinical Pathology Vol. 39, No. 1, (March 2010), pp. 72-78, ISSN 0275-6382

Chen, H.H., Lin, J.H., Fung, H.P., Ho, L.L., Yang, P.C., Lee, W.C., Lee, Y.P. \& Chu, R.M. (2003). Serum acute phase proteins and swine health status. Canadian Journal of Veterinary Research Vol. 67, No. 4, (October 2003), pp. 283-290, ISSN 0830-9000

Clapperton, M., Bishop, S.C., Glass, E.J. (2005). Innate immune traits differ between Meishan and Large White pigs. Veterinary Immunology and Immunopathology, Vol. 104, No. 34, (April 2005), pp. 131-144, ISSN 0165-2427

Clapperton, M., Bishop, S.C., Piñeiro, M., Campbell, F.M., Glass, E.J. (2007). The association between plasma levels of acute phase proteins, hatoglobin, alpha-1 acid glycoprotein (AGP), Pig-MAP, transthyretin and serum amyloid A (SAA) in Large White and Meishan pigs. Veterinary Immunology and Immunopathology, Vol. 119, No. 3-4, (October 2007), pp. 303-309, ISSN 0165-2427

Cohen, N.D.; Chaffin, M.K., Vandenplas, M.L., Edwards, R.F., Nevill, M., Moore, J.N. \& Martens, R.J. (2005). Study of serum amyloid A concentrations as a means of achieving early diagnosis of Rhodococcus equi pneumonia. Equine Veterinary Journal Vol. 37, No. 3, (May 2005), pp.212-216, ISSN 2042-3306

Colditz, I.G.; Lloyd, J.B., Paull, D.R., Lee, C., Giraudo, A., Pizzato, C. \& Fisher, A.D. (2009). Effect of the non-steroidal anti-inflammatory drug, carprofen, on weaned sheep following non-surgical mulesing by intradermal injection of cetrimide. Australian Veterinary Journal Vol. 87, No. 1, (January-February 2009), pp. 19-26, ISSN 1751-0831

Colditz, I.G.; Walkden-Brown, S.W., Daly, B.L. \& Crook, B.J. (2005). Some physiological responses associated with reduced wool growth during blowfly strike in Merino sheep. Australian Veterinary Journal Vol. 83, No. 11, (November 2005), pp. 695-699, ISSN 1751-0831 
Conner, J.G., Eckersall, P.D., Wiseman, T.C., Aitchison, T.C., Douglas, T.A. (1988). Bovine acute phase response following turpentine injection. Research in Veterinary Science, Vol. 44, No. 1, (January 1988), pp. 82-88, ISSN 1540-2681

Correa, S.S.; Mauldin, G.N.; Mauldin, G.E. \& Mooney, S.C. (2001). Serum alpha 1-acid glycoprotein concentration in cats with lymphoma. Journal of the American Animal Hospital Association, Vol. 37, No. 2, (March 2001), pp. 153-158, ISSN 0587-2871

Crisman, M.V.; Scarratt, W.K. \& Zimmerman, K.L. (2008). Blood proteins and inflammation in the horse. Veterinary Clinics of North America: Equine Practice, Vol. 24, No. 2, (August 2008), pp. 285-297, ISSN 0749-0739

Dabrowski, R.; Kostro, K.; Lisiecka, U.; Szczubiał, M. \& Krakowski, L. (2009). Usefulness of C-reactive protein, serum amyloid A component, and haptoglobin determinations in bitches with pyometra for monitoring early post-ovariohysterectomy complications. Theriogenology, Vol. 72, No. 4, (September 2009), pp. 471-476, ISSN 0093-691X

de la Concha-Bermejillo, A.; Singh, B., Whitney, M.S. \& Bazer, F.W. (2000). Acute-phase proteins and hematologic values in ovine lentivirus-infected lambs treated with recombinant ovine IFN-tau. Journal of Interferon $\mathcal{E}$ Cytokine Research Vol. 20, No. 1, (January 2000), pp. 41-53, ISSN 1557-7465

Diack, A.B., Gladney C.D., Mellencamp, M.A., Stear M.J., Eckersall, P.D. (2011). Characterisation of plasma acute phase protein concentrations in a high health boar herd. Veterinary Immunology and Immunopathology, Vol. 139, No. 2-4 (February 2011), pp. 107-112, ISSN 0165-2427

Dow, T.L.; Rogers-Nieman, G., Holásková, I., Elsasser, T.H. \& Dailey, R.A. (2010). Tumor necrosis factor-alpha and acute-phase proteins in early pregnant ewes after challenge with peptidoglycan-polysaccharide. Domestic Animal Endocrinology Vol. 39, No. 2, (August 2010), pp. 147-154, ISSN 0739-7240

Dowling, A.; Hodgson, J.C.; Schock, A.; Donachie, W.; Eckersall, P.D. \& Mckendrick, I.J. (2002). Experimental induction of pneumonic pasteurellosis in calves by intratracheal infection with Pasteurella multocida biotype A:3. Research in Veterinary Science, Vol. 73, No. 1, (August 2002), pp. 37-44, ISSN 0034-5288

Duggan, V. (2008). Serum amyloid A in the neonatal foal: the significance of peri-parturient events. The Veterinary Journal, Vol. 176, No.3, (June 2008), pp. 267-269, ISSN 10900233

Duthie, S.; Eckersall, P.D.; Addie, D.P.; Lawrence C.E. \& Jarret, O. (1997). Value of a1-acid glycoprotein in the diagnosis of feline infectious peritonitis. Veterinary Record, Vol. 141, No. 12, (September 1997), pp. 299-303, ISSN 2042-7670

Earley, B., and Murray, M. (2010). The effect of road and sea transport on inflammatory, adrenocoritcal, metabolic and behavioural responses of weanling heifers. BMC Veterinary Research Vol. 6, No.1, (July 2010), pp. 36, ISSN 1746-6148

Eckersall, P.D. \& Bell, R. (2010). Acute phase proteins: biomarkers of infection and inflammation in veterinary medicine. The Veterinary Journal, Vol. 185, No. 1, (July 2010), pp. 23-27, ISSN 1090-0233

Eckersall, P.D. (2000). Acute phase proteins as markers of infection and inflammation: monitoring animal health, animal welfare and food safety. Irish Veterinary Journal, Vol. 53, No. 6, (June 2000), pp. 307-311, ISSN 0368-0762 
Eckersall, P.D. (2000). Recent advances and future prospects for the use of acute phase proteins as markers of disease in animals. Revue de Médicine Vétérinaire Vol. 151, pp. 577-584, ISSN 0035-1555

Eckersall, P.D.; Lawson, F.P., Bence, L., Waterston, M.M., Lang, T.L., Donachie, W. \& Fontaine, M.C. (2007). Acute phase protein response in an experimental model of ovine caseous lymphadenitis. BMC Veterinary Research, Vol. 3, No. 35, (December 2007), doi:10.1186/1746-6148-3-35, ISSN 1746-6148

Eckersall, P.D.; Lawson, F.P., Kyle, C.E., Waterston, M., Bence, L., Stear, M.J. \& Rhind, S.M. (2008). Maternal undernutrition and the ovine acute phase response to vaccination. BMC Veterinary Research Vol. 15, No. 4, (January 2008), pp. 1, ISSN 1746-6148

Eckersall, P.D.; Young, F.J., Nolan, A.M., Knight, C.H., McComb, C., Waterston, M.M., Hogarth, C.J., Scott, E.M. \& Fitzpatrick, J.L. (2006). Acute phase proteins in bovine milk in an experimental model of Staphylococcus aureus subclinical mastitis. Journal of Dairy Science Vol. 89, No. 5, (May 2006), pp. 1488-1501, ISSN 0022-0302

Eckersall, P.D.; Young, F.J.; McComb, C.; Hogarth, C.J.; Safi, S.; Weber, A.; McDonald, T.; Nolan, A.M. \& Fitzpatrick, J.L. (2001). Acute phase proteins in serum and milk from dairy cows with clinical mastitis. Veterinary Record, Vol. 148, No. 2, (January 2001), pp. 35-41, ISSN 2042-7670

Eicher, S.D. \& Burton, J.L. (2005). Immune system: stress effects, In. Encyclopedia of Animal Science. Pond and Bell, pp. 541-547, ed. Marcel Dekker, ISBN 0-8247-4796-8, New York, NY

Fazio, F.; Assenza, A., Tosto, F., Casella, S., Piccione, G. \& Caola, G. (2010). Modifications of some acute phase proteins and the white blood cell count in thoroughbreds during training. Veterinary Record Vol. 167, No. 10, (September 2010), pp. 370-373, ISSN 0042-4900

Fisher, A.D., Niemeyer, D.O., Lea, J.M., Lee, C., Paull, D.R., Reed, M.T., Ferguson, D.M. (2010). The effects of 12,30 or, 48 hours or road transport on the physiological and behavioural responses of sheep. Journal of Animal Science Vol. 88, No. 6, (June 2010), pp. 2144-2152, ISSN 1525-3163

Francisco, C.J.; Shryock, T.R., Bane, D.P. \& Unverzagt, L. (1996). Serum haptoglobin concentration in growing swine after intranasal challenge with Bordetella bronchiseptica and toxigenic Pasteurella multocida type D. Canadian Journal of Veterinary Research Vol. 20, N0. 3, (July 1996), pp. 222-227, ISSN 0830-9000

Frank, J-W., Mellencamp, M.A., Carroll, J.A., Boys, R.D., Allee, G.L., (2005). Acute feed intake and acute-phase responses following a lipopolysaccharide challenge in pigs from two dam lines. Veterinary Immunology Immunopathology Vol. 107, No. 3-4, (September 2005), pp.179-187, ISSN 0165-2427

Gabler, C., Fischer, C., Drillich, M., Einspanier, R. \& Heuwieser, W. (2010). Time-dependent mRNA expression of selected pro-inflammatory factors in the endometrium of primiparous cows postpartum. Reproduction Biology and Endocrinology Vol. 22, No.8, (December 2010), pp. 152, ISSN 1477-7827

Gånheim, C.; Hultén, C., Carlsson, U., Kindahl, H., Niskanen, R. \& Waller, K.P. (2003). The acute phase response in calves experimentally infected with bovine viral diarrhoea virus and/or Mannheimia haemolytica. Journal of Veterinary Medicine B, Infectious Diseases and Veterinary Public Health Vol. 50, No. 4, (May 2003), pp. 183-190, ISSN 0931-1793. 
Gerardi, G.; Bernardini, D., Azzurra Elia, C., Ferrari, V., Iob, L. \& Segato, S. (2009). Use of serum amyloid A and milk amyloid A in the diagnosis of subclinical mastitis in dairy cows. Journal of Dairy Research, Vol. 76, No. 4, (November 2009), pp. 411-417, ISSN 0022-0299G

Giordano, A.; Spagnolo, V., Colombo, A. \& Paltrinieri, S. (2004). Changes in some acute phase protein and immunoglobulin concentrations in cats affected by feline infectious peritonitis or exposed to feline coronavirus infection. The Veterinary Journal, Vol. 167, No. 1, (July 2010), pp. 38-44, ISSN 1090-0233

Glass E.J. \& Jensen, K. (2007). Resistance and susceptibility to a protozoan parasite of cattle-gene expression differences in macrophages from different breeds of cattle. Veterinary Immunology and Immunopathology Vol. 120, No. 1-2, (November 2007), pp. 20-30, ISSN 0165-2427

Gómez-Laguna, J.; Gutiérrez, A.; Pallarés, F.J.; Salguero, F.J.; Cerón, J.J. \& Carrasco, L. (2010a). Haptoglobin and C-reactive protein as biomarkers in the serum, saliva and meat juice of pigs experimentally infected with porcine reproductive and respiratory syndrome virus. The Veterinary Journal, Vol. 185, No. 1, (July 2010), pp. 83-87, ISSN 1090-0233

Gómez-Laguna, J.; Salguero, F.J.; Pallarés, F.J.; Fernández de Marco, M.; Barranco, I.; Cerón, J.J.; Martínez-Subiela, S.; Van Reeth, K. \& Carrasco, L. (2010b). Acute phase response in porcine reproductive and respiratory syndrome virus infection. Comparative Immunology, Microbiology and Infectious Diseases, Vol. 33, No. 6, (December 2010), pp. e51-e58, ISSN 0970-9320

González, F.H.; Hernández, F.; Madrid, J., Martínez-Subiela, S., Tvarijonaviciute, A., Cerón, J.J. \& Tecles, F. (2011). Acute phase proteins in experimentally induced pregnancy toxemia in goats. Journal of Veterinary Diagnostic Investigation, Vol. 23, No. 1, (January 2011), pp. 57-62, ISSN 1040-6387

González, F.H.; Tecles, F., Martínez-Subiela, S., Tvarijonaviciute, A., Soler, L. \& Cerón, J.J. (2008). Acute phase protein response in goats. Journal of Veterinary Diagnostic Investigation, Vol. 20, No. 5, (September 2008), pp. 580-584, ISSN 1040-6387

González, L.A., Ferret, A., Manteca, X., Ruíz de la Torre, J.L., Calsamiglia, S., Devant, M., Bach, A. (2008). Performance, behavior, and welfare of Friesian heifers housed in pens with two, four, and eight individuals per concentrate feeding place. Journal of Animal Science Vol. 86, No. 6, (June 2008), pp. 1446-1458, ISSN 0021-8812

Grandin, T. (1997). Assessment of stress during handling and transport. Journal of Animal Science Vol. 75, No. 1, (January 1997), pp. 249-257, ISSN 0021-8812

Grau-Roma, L.; Heegaard, P.M.; Hjulsager, C.K.; Sibila, M.; Kristensen, C.S.; Allepuz, A.; Piñeiro, M.; Larsen, L.E.; Segalés, J. \& Fraile, L. (2009). Pig-major acute phase protein and haptoglobin serum concentrations correlate with PCV2 viremia and the clinical course of postweaning multisystemic wasting syndrome. Veterinary Microbiology Vol. 138, No. 1-2, (July 2009), pp. 53-61, ISSN 0378-1135

Griebsch, C.; Arndt, G., Raila, J., Schweigert, F.J. \& Kohn, B. (2009). C-reactive protein concentration in dogs with primary immune-mediated hemolytic anemia. Veterinary Clinical Pathology Vol. 38, No. 4, (December 2009), pp. 421-425, ISSN 0275-6382

Gruys, E.; Toussaint, M.J., Upragarin, N., Van, E.A., Adewuyi, A.A., Candiani, D., Nguyen, T.K. \&, Sabeckiene, J. (2005). Acute phase reactants, challenge in the near future of 
animal production and veterinary medicine. Journal of Zhejiang University SCIENCE B Vol. 6, No. 10, (October 2005), pp. 941-947, ISSN 1673-1581

Gutiérrez, A.M.; Martínez-Subiela, S.; Eckersall, P.D. \& Cerón, J.J. (2009). C-reactive protein quantification in porcine saliva: a minimally invasive test for pig health monitoring. The Veterinary Journal, Vol. 181, No. 3, (September 2009), pp. 261-265, ISSN 10900233

Gutiérrez, A.M.; Martínez-Subiela, S.; Montes, A.; Parra, M.D. \& Cerón, J.J. (2008). C-reactive protein measurements in meat juice of pigs. Veterinary Immunology and Immunopathology, Vol. 122, No. 3-4, (April 2008), pp. 250-255, ISSN 0165-2427

Gutiérrez, A.M.; Yelamos, J., Pallarés, F.J., Gómez-Laguna, J. \& Cerón, J.J. (2011) Monoclonal antibody development and its use for local identification of porcine haptoglobin in salivary gland and diaphragmatic muscle tissues. Histology and Histopathology (in press), ISSN 1699-5848

Guzelbektes, H.; Sen, I., Ok, M., Constable, P.D., Boydak, M. \& Coskun, A. (2010). Serum amyloid $\mathrm{A}$ and haptoglobin concentrations and liver fat percentage in lactating dairy cows with abomasal displacement. Journal of Veterinary Internal Medicine, Vol. 24, No. 1, (January-February 2010), pp. 223-219, ISSN 0891-6640

Hayashi, S.; Jinbo, T., Iguchi, K., Shimizu, M., Shimada, T., Nomura, M., Ishida, Y. \& Yamamoto, S. (2001). A comparison of the concentrations of C-reactive protein and alpha1-acid glycoprotein in the serum of young and adult dogs with acute inflammation. Veterinary Research Communications, Vol. 25, No. 2, (February 2001), pp. 117-126, ISSN 0165-7380

Heegaard, P.M., Klausen, J., Nielsen, J.P., González-Ramón, N., Piñeiro, M., Lampreave, F., Alava, M.A. (1998). The porcine acute phase response to infection with Actinobacillus pleuropneumoniae. Haptoglobin, C-reactive protein, major acute phase protein and serum amyloid A protein are sensitive indicators of infection. Comparative Biochemistry and Physiology B Vol. 119, No. 2, (February 1998), pp. 365373, ISSN 0305-0491

Heegaard, P.M.; Godson, D.L., Toussaint, M.J., Tjørnehøj, K., Larsen, L.E., Viuff, B. \& Rønsholt, L. (2000). The acute phase response of haptoglobin and serum amyloid A (SAA) in cattle undergoing experimental infection with bovine respiratory syncytial virus. Veterinary Immunology and Immunopathology Vol. 77, No. 1-2, (November 2000), pp. 151-159, ISSN 0165-2427

Heegaard, P.M.; Stockmarr, A., Piñeiro, M., Carpintero, R., Lampreave, F., Campbell, F.M., Eckersall, P.D., Toussaint, M.J., Gruys, E. \& Sorensen, N.S. (2011). Optimal combinations of acute phase proteins for detecting infectious disease in pigs. Veterinary Research Vol. 42, No. 1, (March 2011), pp.50, ISSN 0165-7380

Heinonen, M.; Orro, T., Kokkonen, T., Munsterhjelm, C., Peltoniemi, O. \& Valros, A. Tail biting induces a strong acute phase response and tail-end inflammation in finishing pigs. The Veterinary Journal, Vol. 184, No. 3, (June 2010), pp. 303-307, ISSN 1090-0233

Hernandez-Richter, T.M.; Wichmann, M.W.; Schrödl, W., Angele, M.K., Heinritzi, K. \& Schildberg, F.W. (2001). The acute phase response following implantation of triclosan-bonded vascular prostheses. Clinical and Experimental Medicine Vol. 1, No. 1, (March 2001), pp. 35-41, ISSN 1940-5901 
Hirvonen, J.; Hietakorpi, S. \& Saloniemi, H. (1997). Acute phase response in emergency slaughtered dairy cows. Meat Science, Vol. 46, No. 3; (July 1997), pp. 249-257, ISSN 0309-1740

Hiss, S.; Willbrenning, G.S., Suntz, M., Reinacher, M. \& Sauerwein, H. (2008). Immunohistochemical localization of haptoglobin in porcine lungs. Anatomia Histologia Embryologia, Vol. 37, No. 3, (June 2008), pp. 166-169, ISSN 1439-0264

Hobo, S.; Niwa, H., \& Anzai, T. (2007). Evaluation of serum amyloid A and surfactant protein D in sera for identification of the clinical condition of horses with bacterial pneumonia. Journal of Veterinary Medical Science, Vol. 69, No. 8; (August 2007), pp. 827-830, ISSN 0916-7250

Höfner, M.C.; Fosbery, M.W., Eckersall, P.D. \& Donaldson, A.I. (1994). Haptoglobin response of cattle infected with foot-and-mouth disease virus. Research in Veterinary Science Vol. 57, No. 1, (July 1994), pp.125-128, ISSN 0034-5288

Horadagoda, A.; Eckersall, P.D., Hodgson, J.C., Gibbs, H.A. \& Moon, G.M. (1994). Immediate responses in serum TNF alpha and acute phase protein concentrations to infection with Pasteurella haemolytica A1 in calves. Research in Veterinary Science, Vol. 57, No. 1, (July 1994), pp. 129-132, ISSN 0034-5288

Horadagoda, N.U.; Knox, K.M.; Gibbs, H.A.; Reid, S.W.; Horadagoda, A.; Edwards, S.E. \& Eckersall, P.D., (1999). Acute phase proteins in cattle: discrimination between acute and chronic inflammation. Veterinary Record, Vol. 144, No. 16, (April 1999), pp. 437441, ISSN 2042-7670

Hultén, C. \& Demmers, S. (2002). Serum amyloid A (SAA) as an aid in the management of infectious disease in the foal: comparison with total leucocyte count, neutrophil count and fibrinogen. Equine Veterinary Journal Vol. 34, No. 7, (November 2002), pp. 693-698, ISSN 2042-3306

Hultén, C.; Grönlund, U., Hirvonen, J., Tulamo, R.M., Suominen, M.M., Marhaug, G. \& Forsberg, M. (2002). Dynamics in serum of the inflammatory markers serum amyloid A (SAA), haptoglobin, fibrinogen and alpha2-globulins during induced noninfectious arthritis in the horse. Equine Veterinary Journal Vol. 34, No. 7, (November 2002), pp. 699-704, ISSN 2042-3306

Hultén, C.; Sandgren, B., Skiöldebrand, E., Klingeborn, B., Marhaug, G. \& Forsberg, M. (1999). The acute phase protein serum amyloid A (SAA) as an inflammatory marker in equine influenza virus infection. Acta Veterinaria Scandinavica Vol. 40, No. 4, pp. 323-333, ISSN 0044-605X

Humblet, M.F.; Guyot, H., Boudry, B., Mbayahi, F., Hanzen, C., Rollin, F. \& Godeau, J.M. Relationship between haptoglobin, serum amyloid A, and clinical status in a survey of dairy herds during a 6-month period. Veterinary Clinical Pathology Vol. 35, No. 2, (June 2006), pp. 188-193, ISSN 0275-6382

Huntoon, K.M.; Wang, Y., Eppolito, C.A., Barbour, K.W., Berger, F.G., Shrikant, P.A. \& Baumann, H. (2008). The acute phase protein haptoglobin regulates host immunity. Journal of leukocyte biology Vol. 84, No. 1, pp. 170-181.

Huzzey, J.M.; Duffield, T.F., LeBlanc, S.J., Veira, D.M., Weary, D.M. \& von Keyserlingk, M.A. (2009). Short communication: Haptoglobin as an early indicator of metritis. Journal of Dairy Science, Vol. 92, No. 2, (February 2009), pp. 621-625, ISSN 0022-0302

Jacobsen, S.; Halling-Thomsen, M. \& Nanni, S. (2006b). Concentrations of serum amyloid A in serum and synovial fluid from healthy horses and horses with joint disease. 
American Journal of Veterinary Research, Vol. 67, No. 10, (October 2006), pp. 17381742, ISSN 0891-6640

Jacobsen, S.; Nielsen, J.V.; Kjelgaard-Hansen, M.; Toelboell, T.; Fjeldborg, J.; HallingThomsen, M.; Martinussen, T. \& Thoefner, M.B. (2009). Acute phase response to surgery of varying intensity in horses: a preliminary study. Veterinary Surgery, Vol. 38, No. 6 (August 2009), pp. 762-769, ISSN 0161-3499

Jacobsen, S.; Niewold, T.A.; Halling-Thomsen, M.; Nanni, S.; Olsen, E.; Lindegaard, C. \& Andersen, P.H. (2006a). Serum amyloid A isoforms in serum and synovial fluid in horses with lipopolysaccharide-induced arthritis. Veterinary Immunology and Immunopathology, Vol. 110, No. 3-4 (April 2006), pp. 325-330, ISSN 0165-2427

Jacobson, M.; Fellström, C., Lindberg, R., Wallgren, P. \& Jensen-Waern, M. (2004). Experimental swine dysentery: comparison between infection models. Journal of Medical Microbiology Vol. 53, No. Pt 4, (April 2004), pp. 273-280, ISSN 1473-5644

Jergens, A.E.; Schreiner, C.A.; Frank, D.E.; Niyo, Y.; Ahrens, F.E.; Eckersall, P.D.; Benson, T.J. \& Evans, R. (2003). A scoring index for disease activity in canine inflammatory bowel disease. Journal of Veterinary Internal Medicine, Vol. 17, No. 3, (May 2003), pp. 291-297, ISSN 0891-6640

Johnson, A.K.; Mitloehner, F.M., Morrow, J.L. \& McGlone, J.J. (2008). Effects of shaded versus unshaded wallows on behaviour, performance, and physiology of the outdoor lactating sow. Journal of Animal Science Vol. 86, No. 12, (December 2008), pp. 3628-3634, ISSN 1523-3163

Jungersen, G.; Jensen, L., Riber, U., Heegaard, P.M., Petersen, E., Poulsen, J.S., Bille-Hansen, V. \& Lind, P. (1999). Pathogenicity of selected Toxoplasma gondii isolates in young pigs. International Journal of Parasitology Vol. 29, No. 8, (August 1999), pp. 1307-1319, ISSN 0020-7519

Kajikawa, T.; Furuta, A., Onishi, T., Tajima, T. \& Sugii, S. (1999). Changes in concentrations of serum amyloid A protein, alpha 1-acid glycoprotein, haptoglobin, and C-reactive protein in feline sera due to induced inflammation and surgery. Veterinary Immunology and Immunopathology Vol. 68, No. 1, (March 1999), pp. 91-98, ISSN 0165-2427

Katoh, N. \& Nakagawa, H. (1999). Detection of haptoglobin in the high-density lipoprotein and the very high-density lipoprotein fractions from sera of calves with experimental pneumonia and cows with naturally occurring fatty liver. Journal of Veterinary Medical Science Vol. 61, No. 2, (February 1999), pp. 119-124, ISSN 09167250

Khafipour, E.; Krause, D.O. \& Plaizier, J.C. (2009). A grain-based subacute ruminal acidosis challenge causes translocation of lipopolysaccharide and triggers inflammation. Journal of Dairy Science Vol. 92, No. 3, (March 2009), pp. 1060-1070, ISSN 0022-0302

Kingston, R.S.; Shih, M.S. \& Snyder, S.P. (1982). Secondary amyloidosis in Dall's sheep. Journal of Wildlife Disease Vol. 18, No. 3, (July 1982), pp. 381-383, ISSN 0090-3558

Knura-Deszczk, S.; Lipperheide, C., Petersen, B., Jobert, J.L., Berthelot-Hérault, F., Kobisch, M. \& Madec, F. (2002). Plasma haptoglobin concentration in swine after challenge with Streptococcus suis. Journal of Veterinary Medicine. B, Infectious Diseases and Veterinary Public Health Vol. 49, No. 5, (June 2002), pp. 240-244. , ISSN 0931-1793.

Kocaturk, M.; Martínez, S.; Eralp, O.; Tvarijonaviciute, A.; Cerón, J. \& Yilmaz, Z. (2010). Prognostic value of serum acute-phase proteins in dogs with parvoviral enteritis. 
Journal of Small Animal Practice, Vol. 51, No. 9, (September 2010), pp. 478-483, ISSN 1748-5827

Krakowski, L.; Krawczyk, C., Kostro, K., Stefaniak, T., Novotny, F. \& Obara, J. (2011). Serum Levels of Acute Phase Proteins: SAA, Hp and Progesterone (P4) in Mares with Early Embryonic Death. Reproduction in Domestic Animals. 2011 Jan 17. doi: 10.1111/j.1439-0531.2010.01715.x, ISSN 0936-6768

Kujala, M.; Orro, T. \& Soveri, T. (2010). Serum acute phase proteins as a marker of inflammation in dairy cattle with hoof diseases. Veterinary Record, Vol. 166, No. 8, (February 2010), pp. 240-241, ISSN 2042-7670

Kuji, T.; Masaki, T., Li, L., Cheung \& A.K. (2007). Expression of C-reactive protein in myointimal hyperplasia in a porcine arteriovenous graft model. Nephrology Dialisys Transplantation Vol. 22, No. 9, (September 2007), pp. 2469-2475, ISSN 14602385

Lee, W.C.; Hsiao, H.C.; Wu, Y.L.; Lin, J.H.; Lee, Y.P.; Fung, H.P.; Chen, H.H.; Chen, Y.H. \& Chu, R.M. (2003). Serum C-reactive protein in dairy herds. Canadian Journal of Veterinary Research, Vol. 67, No. 2, (May 2003), pp. 102-107, ISSN 0830-9000

Lepherd, M.L.; Canfield, P.J., Hunt, G.B., Thomson, P.C. \& Bosward, K.L. (2011). Assessment of the short-term systemic effect of an acute phase response to mulesing and other options for controlling breech flystrike in Merino lambs. Australian Veterinary Journal Vol. 89, No. 1-2, (January 2011), pp. 19-26, ISSN 1751-0831

Lobetti, R.G.; Möhr, A.J., Dippenaar, T. \& Myburgh, E. (2000). A preliminary study on the serum protein response in canine babesiosis. Journal of the South African Veterinary Association, Vol. 71, No. 1, (March 2000), pp. 38-42, ISSN 0038-2809

Lomborg, S.R.; Nielsen, L.R., Heegaard, P.M. \& Jacobsen, S. (2008). Acute phase proteins in cattle after exposure to complex stress. Veterinary Research Communications, Vol. 32, No. 7, (October 2008), pp. 575-582, ISSN 0165-7380

Lowrie, M.; Penderis, J., McLaughlin, M., Eckersall, P.D. \& Anderson, T.J. (2009). Steroid responsive meningitis-arteritis: a prospective study of potential disease markers, prednisolone treatment, and long-term outcome in 20 dogs (2006-2008). Journal of Veterinary Internal Medicine, Vol. 23, No. 4, (July-August 2009), pp. 862-870, ISSN 0891-6640

Lynch, E.M.; Earley, B., McGee, M. \& Doyle, S. (2010). Characterisation of physiological and immunological responses in beef cows to abrupt weaning and subsequent housing. BMC Veterinary Research Vol. 20, No. 6, (July 2010), pp. 37, ISSN 1746-6148

Mackiewicz, A. (1997). Acute phase proteins and transformed cells. International Review of Cytology Vol. 170, (1997), pp. 225-300, ISSN 0074-7696

Magnusson, U.; Wilkie, B., Artursson, K. \& Mallard, B. (1999). Interferon-alpha and haptoglobin in pigs selectively bred for high and low immune response and infected with Mycoplasma hyorhinis. Veterinary Immunology and Immunopathology Vol. 68, No.2-4, (May 1999), pp. 131-137, ISSN 0165-2427

Marco-Ramell, A.; Pato, R., Peña, R., Saco, Y., Manteca, X., Ruiz de la Torre, J.L. \& Bassols A. (2011). Identification of serum stress biomarkers in pigs housed at different stocking densities. The Veterinary Journal, doi:10.1016/j.tvjl.2011.01.003, (February 2011), ISSN 1090-0233

Martín de la Fuente, A.J.; Carpintero, R., Rodríguez Ferri, E.F., Alava, M.A., Lampreave, F. \& Gutiérrez Martín, C.B. (2010). Acute-phase protein response in pigs experimentally 
infected with Haemophilus parasuis. Comparative Immunology, Microbiology $\mathcal{E}$ Infectious Disease Vol. 33, No. 6, (December 2010), pp. 455-465, ISSN 0970-9320

Martín, M., Tesouro, M.A., Gonz Am, N., Pi, A., Lampreave, F. (2005). Major plasma proteins in pig serum during postnatal development. Reproduction, Fertility, and Development Vol. 17, No. 4 (2005), pp. 439-445, ISSN 1031-3613

Martínez-Subiela, S.; Bernal, L.J., Cerón, J.J. (2003). Serum concentrations of acute-phase proteins in dogs with leishmaniosis during short-term treatment. American Journal of Veterinary Research Vol. 64, No. 8, (August 2003), pp. 1021-1026, ISSN 0891-6640

Martínez-Subiela, S.; Tecles, F., Eckersall, P.D. \& Cerón, J.J. (2002). Serum concentrations of acute phase proteins in dogs with leishmaniasis. Veterinary Record, Vol. 150, No. 8, (February 2002), pp. 241-244, ISSN 2042-7670

Mastrorilli, C.; Dondi, F., Agnoli, C., Turba, M.E., Vezzali, E. \& Gentilini, F. (2007). Clinicopathologic features and outcome predictors of Leptospira interrogans Australis serogroup infection in dogs: a retrospective study of 20 cases (2001-2004). Journal of Veterinary Internal Medicine Vol. 21, No. 1, (January-February 2007), pp. 310, ISSN 0891-6640

Matijatko, V.; Mrljak, V., Kis, I., Kucer, N., Forsek, J., Zivicnjak, T., Romi, Z., Simec, Z. \& Ceron, J.J. (2007). Evidence of an acute phase response in dogs naturally infected with Babesia canis. Veterinary Parasitology, Vol. 144, No. 3-4, (March 2007), pp. 242250, ISSN 0304-4017

McCobb, E.C., Patronek, G.J., Marder, A., Dinnage, J.D., Stone, M.S. (2005). Assessment of stress levels among cats in four animal shelters. Journal of the American Veterinary Medical Association Vol. 226, No. 4, (February 2005), pp. 548-555, ISSN 0003-1488

Meade, K.G., O'Gorman, G.M., Hill, E.W., Narciandi, F., Agaba, M., Kemps S.J., O'Farrellys C., MacHughs D.E (2009). Divergent antimicrobial peptide (AMP) and acute phase protein (APP) responses to Trypanosoma congolense infection in trypanotolerant and trypanosusceptible cattle. Mol Immunol. 2009 Dec;47(2-3):196-204.

Mette, C.; Dooleweerdt B.C., Stine, J., Miki B. A., Roenn P.M. \& Henrik LJ. (2010). Evaluation of the systemic acute phase response and endometrial gene expression of serum amyloid A and pro- and anti-inflammatory cytokines in mares with experimentally induced endometritis. Veterinary Immunology and Immunopathology, Vol. 138, No. 1-2 (November 2010), pp. 95-105, ISSN 0165-2427

Miller, K. \& Wood-Gush, D.G.M. (1991). Some effects of housing on the social behavior of dairy cows. Animal Production Vol. 53, pp. 271-278, ISSN 0003-3561

Millet, S., Cox, E., Buyse, J., Goddeeris, B.M., Janssens, G.P.J. (2005). Immunocompetence of fatteing pigs fed organic versus conventional diets in organic versus conventional housing. The Veterinary Journal Vol. 169, No. 2, (March 2005), pp. 293-299, ISSN 1090-0233

Milne, E.M.; Doxey, D.L., Kent, J.E. \& Pemberton, A. (1991). Acute phase proteins in grass sickness (equine dysautonomia). Research in Veterinary Science Vol. 50, No. 3, (May 1991), pp. 273-278, ISSN 0034-5288

Mischke, R.; Waterston, M. \& Eckersall, P.D. (2007). Changes in C-reactive protein and haptoglobin in dogs with lymphatic neoplasia. The Veterinary Journal, Vol. 174, No. 1, (July 2007), pp. 188-192, ISSN 1090-0233 
Mitchell, K.D., Kruth, S.A., Wood, R.D. \& Jefferson, B. (2009). Serum acute phase protein concentrations in dogs with autoimmune hemolytic anemia. Journal of Veterinary Internal Medicine Vol. 23, No. 3, pp. 585-591, ISSN 0891-6640

Moestrup, S.K. \& Moller, H.J. (2004). CD163: a regulated hemoglobin scavenger receptor with a role in the anti-inflammatory response. Annals of Medicine Vol. 36, No. 5, pp. 347-354, ISSN 0785-3890

Murata, H. \& Miyamoto, T. (1993). Bovine haptoglobin as a possible immunomodulator in the sera of transported calves. The British Veterinary Journal Vol. 149, No. 3, (MayJune 1993), pp. 277-283, ISSN 0007-1935

Murata, H.; Shimada, N. \& Yoshioka, M. (2004). Current research on acute phase proteins in veterinary diagnosis: an overview. The Veterinary Journal, Vol. 168, No. 1, (July 2004), pp. 28-40, ISSN 1090-0233

Nakamura, M.; Takahashi, M., Ohno, K., Koshino, A., Nakashima, K., Setoguchi, A., Fujino, Y. \& Tsujimoto, H. (2008). C-reactive protein concentration in dogs with various diseases. Journal of Veterinary Medical Science Vol. 70, No. 2, (February 2008), pp. 127-131, ISSN 0916-7250

Nazifi, S.; Ansari-Lari, M., Asadi-Fardaqi, J. \& Rezaei, M. (2009a). The use of receiver operating characteristic (ROC) analysis to assess the diagnostic value of serum amyloid $\mathrm{A}$, haptoglobin and fibrinogen in traumatic reticuloperitonitis in cattle. The Veterinary Journal Vol. 182, No. 2, (November 2009), pp. 315-319, ISSN 1090-0233

Nazifi, S.; Razavi, S.M., Esmailnejad, Z. \& Gheisari, H. (2009b). Study on acute phase proteins (haptoglobin, serum amyloid A, fibrinogen, and ceruloplasmin) changes and their diagnostic values in bovine tropical theileriosis. Parasitology Research Vol. 105, No. 1, (July 2009), pp. 41-46, ISSN 0932-0113

Ndung'u, J.M.; Eckersall, P.D. \& Jennings, F.W. (1991). Elevation of the concentration of acute phase proteins in dogs infected with Trypanosoma brucei. Acta Tropica Vol. 49, No. 2, (June 1991), pp. 77-86, ISSN 0001-706X

Nielsen, L.; Toft, N., Eckersall, P.D., Mellor, D.J. \& Morris, J.S. (2007). Serum C-reactive protein concentration as an indicator of remission status in dogs with multicentric lymphoma. Journal of Veterinary Internal Medicine Vol. 21, No. 6, (NovemberDecember 2007), pp. 1231-1236, ISSN 0891-6640

Nikunen, S.; Härtel, H., Orro, T., Neuvonen, E., Tanskanen, R., Kivelä, S.L., Sankari, S., Aho, P., Pyörälä, S., Saloniemi, H. \& Soveri, T. (2007). Association of bovine respiratory disease with clinical status and acute phase proteins in calves. Comparative Immunology, Microbiology and Infectious Diseases, Vol. 30, No. 3, (May 2007), pp. 143151, ISSN 0970-9320

Nunokawa, Y.; Fujinaga, T., Taira, T., Okumura, M., Yamashita, K., Tsunoda, N. \& Hagio, M. (1993). Evaluation of serum amyloid A protein as an acute-phase reactive protein in horses. Journal of Veterinary Medical Science Vol. 55, No. 6, (December 1993), pp. 1011-1016, ISSN 0916-7250

Ogilvie, G.K.; Walters, L.M., Greeley, S.G., Henkel, S.E., Salman, M.D. (1993). Concentration of alpha 1-acid glycoprotein in dogs with malignant neoplasia. Journal of the American Veterinary Medical Association Vol. 203, No. 8, (October 1993), pp. 11441146, ISSN 0003-1488

O'Meara, T.J.; Nesa, M., Seaton, D.S. \& Sandeman, R.M. (1995). A comparison of inflammatory exudates released from myiasis wounds on sheep bred for resistance 
or susceptibility to Lucilia cuprina. Veterinary Parasitology Vol. 56, No. 1-3, (January 1995), pp. 207-223, ISSN 0304-4017

Orro, T.; Jacobsen, S., LePage, J.P., Niewold, T., Alasuutari, S. \& Soveri, T. (2008). Temporal changes in serum concentrations of acute phase proteins in newborn dairy calves. The Veterinary Journal Vol. 176, No. 2, (May 2008), pp. 182-187, ISSN 1090-0233

Ottenjann, M.; Weingart, C., Arndt, G. \& Kohn, B. (2006). Characterization of the anemia of inflammatory disease in cats with abscesses, pyothorax, or fat necrosis. Journal of Veterinary Internal Medicine, Vol. 2, No. 5, (September-October 2006), pp. 1143-1150, ISSN 0891-6640

Päiväniemi, O.E.; Maasilta, P.K., Vainikka, T.L., Alho, H.S., Karhunen, P.J. \& Salminen, U.S. (2009). Local C-reactive protein expression in obliterative lesions and the bronchial wall in posttransplant obliterative bronchiolitis. Mediators of Inflammation Vol. 2009, (May 2009), pp. 510254, ISSN 1466-1861

Pallarés, F.J.; Martínez-Subiela, S., Seva, J., Ramis, G., Fuentes, P., Bernabé, A., Muñoz, A. \& Cerón, J.J. (2008). Relationship between serum acute phase protein concentrations and lesions in finishing pigs. The Veterinary Journal, Vol. 177, No. 3, (September 2008), pp. 369-373, ISSN 1090-0233

Paltrinieri, S. (2008). The feline acute phase reaction. The Veterinary Journal, Vol. 177, No. 1, (July 2008), pp. 26-35, ISSN 1090-0233

Paltrinieri, S.; Crippa, A., Comerio, T., Angioletti, A. \& Roccabianca, P. (2007). Evaluation of inflammation and immunity in cats with spontaneous parvovirus infection: consequences of recombinant feline interferon-omega administration. Veterinary Immunology and Immunopathology Vol. 118, No. 1-2, (July 2007), pp. 68-74, ISSN 0165-2427

Paltrinieri, S.; Giordano, A., Tranquillo, V. \& Guazzetti, S. (2007). Critical assessment of the diagnostic value of feline alpha1-acid glycoprotein for feline infectious peritonitis using the likelihood ratios approach. Journal of Veterinary Diagnostic Investigation Vol. 19, No. 3, (May 2007), pp. 266-272, ISSN 1040-6387

Paltrinieri, S.; Giordano, A., Villani, M., Manfrin, M., Panzani, S. \& Veronesi, M.C. (2008). Influence of age and foaling on plasma protein electrophoresis and serum amyloid A and their possible role as markers of equine neonatal septicaemia. The Veterinary Journal, Vol. 176, No. 3, (June 2008), pp. 393-396, ISSN 1090-0233

Paltrinieri, S.; Metzger, C., Battilani, M., Pocacqua, V., Gelain, M.E. \& Giordano, A. (2007c). Serum alpha1-acid glycoprotein (AGP) concentration in non-symptomatic cats with feline coronavirus (FCoV) infection. Journal of Feline Medicine and Surgery. Vol. 9, No. 4, (August 2007), pp. 271-277, ISSN 1098-612X

Pantchev, N. (2010). C-reactive protein as a marker in canine granulocitic anaplasmosis. Veterinary Record, Vol. 166, No. 20, (May 2010), p. 632, ISSN 2042-7670

Parra, M.D.; Fuentes, P., Tecles, F., Martínez-Subiela, S., Martínez, J.S., Muñoz, A. \& Cerón, J.J. (2006). Porcine acute phase protein concentrations in different diseases in field conditions. Journal of Veterinary Medicine B, Infectious Diseases and Veterinary Public Health, Vol. 53, No. 10, (December 2006), pp. 488-493, ISSN 0931-1793

Parra, M.D.; Tecles, F.; Martínez-Subiela, S. \& Cerón, J.J. (2005). C-reactive protein measurement in canine saliva. Journal of Veterinary Diagnostic Investigation, Vol. 17, No. 2, (March 2005), pp. 139-144, ISSN 1040-6387 
Paull, D.R.; Lee, C., Atkinson, S.J. \& Fisher, A.D. Effects of meloxicam or tolfenamic acid administration on the pain and stress responses of Merino lambs to mulesing. Australian Veterinary Journal Vol. 86, No. 8, (August 2008), pp. 303-311, ISSN 17510831

Paull, D.R.; Lee, C., Colditz, I.G. \& Fisher, A.D. Effects of a topical anaesthetic formulation and systemic carprofen, given singly or in combination, on the cortisol and behavioural responses of Merino lambs to castration. Australian Veterinary Journal Vol. 87, No. 6, (June 2009), pp. 230-237, ISSN 1751-0831

Pépin, M.; Pardon, P., Lantier, F., Marly, J., Levieux, D. \& Lamand, M. (1991). Experimental Corynebacterium pseudotuberculosis infection in lambs: kinetics of bacterial dissemination and inflammation. Veterinary Microbiology Vol. 26, No. 4, (February 1991), pp. 381-392, ISSN 0378-1135

Petersen, H.H., Ersboll, A.K., Jensen, C.S., Nielsen, J.P. (2002). Serum haptoglobin concentration in Danish slaughter pigs of different health status. Preventive Veterinary Medicine Vol. 54, No. 4, (August 2002), pp. 325-335, ISSN 0167-5877

Petersen, H.H.; Nielsen, J.P. \& Heegaard, P.M. (2004). Application of acute phase protein measurements in veterinary clinical chemistry. Veterinary Research, Vol. 35, No. 2, (March-April 2004), pp. 163-187, ISSN 1746-6148

Pfeffer, A. \& Rogers, K.M. Acute phase response of sheep: changes in the concentrations of ceruloplasmin, fibrinogen, haptoglobin and the major blood cell types associated with pulmonary damage. Research in Veterinary Science Vol. 46, No. 1, (January 1989), pp. 118-124, ISSN 0034-5288

Pfeffer, A.; Rogers, K.M., O'Keeffe, L. \& Osborn, P.J. (1993). Acute phase protein response, food intake, liveweight change and lesions following intrathoracic injection of yeast in sheep. Research in Veterinary Science Vol. 55, No. 3, (November 1993), pp. 360-366, ISSN 0034-5288

Philippidis, P.; Mason, J.C., Evans, B.J., Nadra, I., Taylor, K.M., Haskard, D.O. \& Landis, R.C. (2004). Hemoglobin scavenger receptor CD163 mediates interleukin-10 release and heme oxygenase-1 synthesis: antiinflammatory monocyte-macrophage responses in vitro, in resolving skin blisters in vivo, and after cardiopulmonary bypass surgery. Circulation Research Vol. 94, No. 1, pp. 119-126, ISSN 0009-7300

Piñeiro, C., Piñeiro, M., Morales, J., Andres, M., Lorenzo, E., Pozo, M.D., Alava, M.A., Lampreave, F. (2009). Pig-MAP and haptoglobin concentration reference values in swine from commercial farms. The Veterinary Journal Vol. 179, No. 1, (January 2009), pp. 78-84, ISSN 1090-0233

Piñeiro, C., Piñeiro, M., Morales, J., Carpintero, R., Campbell, F.M., Eckersall, P.D., Toussaint, M.J.M., Alava, M.A. \& Lampreave, F. (2007). Pig acute-phase protein levels after stress induced by changes in the pattern of food administration. Animal Vol. 1, pp. 133-139, ISSN 1751-7311

Piñeiro, M.; Piñeiro, C., Carpintero, R., Morales, J., Campbell, F.M., Eckersall, P.D., Toussaint, M.J. \& Lampreave, F. (2007). Characterisation of the pig acute phase protein response to road transport. The Veterinary Journal, Vol. 173, No. 3, (May 2007), pp.669-674, ISSN 1090-0233

Planellas, M.; Bassols, A., Siracusa, C., Saco, Y., Giménez, M., Pato, R. \& Pastor, J. (2009). Evaluation of serum haptoglobin and C-reactive protein in dogs with mammary 
tumors. Veterinary Clinical Pathology, Vol. 38, No. 3, (September 2009), pp. 348-352, ISSN 0275-6382

Pollock, P.J.; Prendergast, M., Schumacher, J. \& Bellenger, C.R. (2005). Effects of surgery on the acute phase response in clinically normal and diseased horses. Veterinary Record, Vol. 156, No. 17, (April 2005), pp. 538-542, ISSN 2042-7670

Qiu, X.; Arthington, J.D., Riley, D.G., Chase, C.C. Jr., Phillips, W.A., Coleman, S.W. \& Olson, T.A. (2007). Genetic effects on acute phase protein response to the stresses of weaning and transportation in beef calves. Journal of Animal Science Vol. 85, No. 10, (October 2007), pp. 2367-2374, ISSN 1523-3163

Rabehi, L.; Ferriere, F., Saffar, L. \& Gattegno, L. (1995). alpha 1-Acid glycoprotein binds human immunodeficiency virus type 1 (HIV-1) envelope glycoprotein via N-linked glycans. Glycoconjugate Journal Vol. 12, No. 1, (February 1995), pp. 7-16, ISSN 02820080

Rahman, M.M.; Lecchi, C., Fraquelli, C., Sartorelli, P. \& Ceciliani, F. Acute phase protein response in Alpine ibex with sarcoptic mange. Veterinary Parasitology Vol. 168, No. 3-4, (March 2010), pp. 293-298, ISSN 0304-4017

Regassa, F. \& Noakes, D.E. (1999). Acute phase protein response of ewes and the release of PGFM in relation to uterine involution and the presence of intrauterine bacteria. Veterinary Record Vol. 144, No. 18, (May 1999), pp. 502-506, ISSN 2042-7670

Rikihisa, Y.; Yamamoto, S., Kwak, I., Iqbal, Z., Kociba, G., Mott, J. \& Chichanasiriwithaya, W. (1994). C-reactive protein and alpha 1-acid glycoprotein levels in dogs infected with Ehrlichia canis. Journal of Clinical Microbiology Vol. 32, No. 4, (April 1994), pp912-917, ISSN 0095-1137

Rooney, N.J., Gaines, S.A., Bradshaw, J.W. (2007). Behavioural and glucocorticoid responses of dogs (Canis familiaris) to kennelling: Investigating mitigation of stress by prior habituation. Physiology \& Behavior Vol. 92, No. 5, (December 2007), pp. 847-854, ISSN 0031-9384

Sack, G.H.Jr. \& Zink, M.C. (1992). Serum amyloid A gene transcription in synovial cells during retroviral arthritis. American Journal of Pathology Vol. 141, No. 3, (September 1992), pp. 525-529, ISSN 0002-9173

Saco, Y.; Docampo, M., Fàbrega, E., Manteca, X., Diestre, A., Lampreave, F. \& Bassold, A. (2003). Effect of transport stress on serum haptoglobin and Pig-MAP in pigs. Animal Welfare Vol. 12, No. 3, (August 2003), pp. 403-409, ISSN 0962-7286

Saco, Y.; Fina, M., Giménez, M., Pato, R., Piedrafita, J., Bassols, A. (2008). Evaluation of serum cortisol, metabolic parameters, acute phase proteins and faecal corticosterone as indicators of stress in cows. The Veterinary Journal Vol. 177, No. 3, (September 2008), pp. 439-441, ISSN 1090-0233

Saco, Y.; Fraile, L., Giménez, M., Alegre, A., López-Jimenez, R., Cortey, M., Segalés, J. \& Bassols, A. (2010). Serum acute phase proteins as biomarkers of pleuritis and cranio-ventral pulmonary consolidation in slaughter-aged pigs. Research in Veterinary Science, doi:10.1016/j.rvsc.2010.08.016, ISSN 0034-5288

Safi, S.; Khoshvaghti, A., Jafarzadeh, S.R., Bolourchi, M. \& Nowrouzian, I. (2009). Acute phase proteins in the diagnosis of bovine subclinical mastitis. Veterinary Clinical Pathology, Vol. 38, No. 4, (December 2009), pp. 471-476, ISSN 0275-6382

Salamano, G.; Mellia, E., Candiani, D., Ingravalle, F., Bruno, R., Ru, G. \& Doglione, L. (2008). Changes in haptoglobin, C-reactive protein and pig-MAP during a housing period 
following long distance transport in swine. The Veterinary Journal, Vol. 177, No. 1, (July 2008), pp.110-115, ISSN 1090-0233

Sánchez-Cordón, P.J.; Cerón, J.J., Núñez, A., Martínez-Subiela, S., Pedrera, M., RomeroTrevejo, J.L., Garrido, M.R. \& Gómez-Villamandos, J.C. (2007). Serum concentrations of C-reactive protein, serum amyloid $\mathrm{A}$, and haptoglobin in pigs inoculated with African swine fever or classical swine fever viruses. American Journal of Veterinary Research, Vol. 68, No. 7, (July 2007), pp. 772-777, ISSN 0891-6640

Sasaki, K.; Ma, Z.Y., Khatlani, T.S., Okuda, M., Inokuma H. \& Onishi, T. (2003). Evaluation of feline serum amyloid A (SAA) as an inflammatory marker. Journal of Veterinary Medical Science, Vol. 65, No. 4; (April 2003), pp. 545-548, ISSN 0916-7250

Selting, K.A.; Ogilvie, G.K., Lana, S.E., Fettman, M.J., Mitchener, K.L., Hansen, R.A., Richardson, K.L., Walton, J.A. \& Scherk, M.A. (2000). Serum alhpa 1-acid glycoprotein concentrations in healthy and tumor-bearing cats. Journal of Veterinary Internal Medicine Vol. 14, No. 5, (September-October 2000), pp. 503-506, ISSN 08916640

Selye, H. (1998). A syndrome produced by diverse nocuous agents. 1936. The Journal of Neuropsychiatry and Medical Neuroscience Vol. 10, No. 2, (Spring 1998), pp. 230-231, ISSN 1545-7222

Serin, G. \& Ulutas, P.A. (2010). Measurement of serum acute phase proteins to monitor postoperative recovery in anoestrous bitches after ovariohysterectomy. Veterinary Record Vol. 166, No. 1, (January 2010), pp. 20-22, ISSN 2042-7670

Sheahan, D.; Bell, R., Mellanby, R.J., Gow, A.G., Friend, E., Heller, J., Bence, L.M. \& Eckersall, P.D. (2010). Acute phase protein concentrations in dogs with nasal disease. Veterinary Record, Vol. 167, No. 23, (December 2010), pp. 895-899, ISSN 2042-7670

Skinner, J.G. \& Roberts, L. (1994). Haptoglobin as an indicator of infection in sheep. Veterinary Record, Vol. 134, No. 2, (January 1994), pp. 33-36, ISSN 2042-7670

Skovgaard, K.; Mortensen, S., Boye, M., Poulsen, K.T., Campbell, F.M., Eckersall, P.D. \& Heegaard, P.M. (2009). Rapid and widely disseminated acute phase protein response after experimental bacterial infection of pigs. Veterinary Research, Vol. 40, No. 3, doi: 10.1051/vetres/2009006, (May-June 2009), ISSN 1297-9716

Smith, B.I.; Kauffold, J. \& Sherman, L. (2010). Serum haptoglobin concentrations in dairy cattle with lameness due to claw disorders. The Veterinary Journal, Vol. 186, No. 2, (November 2010), pp.162-165, ISSN 1090-0233

Sorensen, N.S.; Tegtmeier, C., Andresen, L.O., Piñeiro, M., Toussaint, M.J., Campbell, F.M., Lampreave, F. \& Heegaard, P.M. (2006). The porcine acute phase protein response to acute clinical and subclinical experimental infection with Streptococcus suis. Veterinary Immunology and Immunopathology, Vol. 113, No. 1-2, (September 2006), pp. 157-168, ISSN 0165-2427

Sorrells, A.D.; Eicher, S.D., Harris, M.J., Pajor, E.A. \& Richert, B.T. (2007). Periparturient cortisol, acute phase cytokine, and acute phase protein profiles of gilts housed in groups or stalls during gestation. Journal of Animal Science Vol. 85, No. 7, (July 2007), pp. 1750-1757, ISSN 1523-3163

Stevenson, L.S., McCullough, K., Vincent, I., Gilpin, D.F., Summerfield, A., Nielsen, J., McNeilly, F., Adair, B.M. \& Allan, G.M. (2006). Cytokine and C-reactive protein 
profiles induced by circovirus type 2 experimental infection in 3-week-old piglets. Viral Immunology Vol. 19, No. 2, (Summer 2006), pp. 189-195, ISSN 0882-8245

Stoddart, M.E.; Whicher, J.T. \& Harbour, D.A. (1988). Cats inoculated with feline infectious peritonitis virus exhibit a biphasic acute phase plasma protein response. Veterinary Record, Vol. 123, No. 24, (December 1988), pp. 622-624, ISSN 2042-7670

Stokka, G.L.; Edwards, A.J., Spire, M.F., Brandt, R.T.Jr. \& Smith, J.E. (1994). Inflammatory response to clostridial vaccines in feedlot cattle. Journal of American Veterinary Medical Association Vol. 204, No. 3, (February 1994), pp. 415-419, ISSN 0003-1488

Suojala, L.; Orro, T., Järvinen, H., Saatsi, J. \& Pyörälä, S. (2008). Acute phase response in two consecutive experimentally induced $E$. coli intramammary infections in dairy cows. Acta Veterinaria Scandinavica Vol. 13, No. 50, (June 2008), pp. 18, ISSN 0044-605X

Sutherland, M.A., Niekamp, S.R., Rodríguez-Zas, S.L., Salak-Johnson, J.L. (2006). Impacts of chronic stress and social status on various physiological and performance measures in pigs of different breeds. Journal of Animal Science Vol. 84, No. 3, (March 2006), pp. 588-596, ISSN 0021-8812

Tabrizi, A.D.; Batavani, R.A., Rezaei, S.A. \& Ahmadi, M. (2008). Fibrinogen and ceruloplasmin in plasma and milk from dairy cows with subclinical and clinical mastitis. Pakistan Journal of Biological Sciences Vol. 11, No. 4, (February 2008), pp. 571-576, ISSN 1028-8880

Tamamoto, T.; Ohno, K., Ohmi, A., Seki, I. \& Tsujimoto, H. (2009). Time-course monitoring of serum amyloid A in a cat with pancreatitis. Veterinary Clinical Pathology, Vol. 38, No. 1, (March 2009), pp. 83-86, ISSN 0275-6382

Tecles, F.; Caldín, M., Zanella, A., Membiela, F., Tvrijonaviciute, A., Martínez-Subiela, S. \& Cerón, J.J. (2009). Serum acute phase protein concentrations in female dogs with mamary tumors. Journal of Veterinary Diagnostic Investigation, Vol. 21, No. 2; (March 2009), pp. 214-219, ISSN 1040-6387

Tecles, F.; Spiranelli, E., Bonfanti, U., Cerón, J.J. \& Paltrinieri, S. (2005). Preliminary studies of serum acute-phase protein concentrations in hematologic and neoplastic diseases of the dog. Journal of Veterinary Internal Medicine Vol. 19, No. 6, (NovemberDecember 2005), pp. 865-870, ISSN 0891-6640

TerWee, J.; Lauritzen, A.Y., Sabara, M., Dreier K.J. \& Kokjohn, K. (1997). Comparison of the primary signs induced by experimental exposure to either a pneumotrophic or a 'limping' strain of feline calicivirus. Veterinary Microbiology Vol. 56, No. 1-2, (May 1997), pp. 33-45, ISSN 0378-1135

TerWee, J.; Sabara, M., Kokjohn, K., Sandbulte, J., Frenchick P. \& Dreier, K.J. (1998). Characterization of the systemic disease and ocular signs induced by experimental infection with Chlamydia psittaci in cats. Veterinary Microbiology Vol. 59, No. 4, (January 1998), pp. 259-281, ISSN 0378-1135

Tóthová, C.; Nagy, O., Seide, H. \& Kovác, G. (2010). The effect of chronic respiratory diseases on acute phase proteins and selected blood parameters of protein metabolism in calves. Berliner und Munchener Tierarztliche Wochenschrift, Vol. 123, No. 7-8, (July-August 2010), pp. 307-313, ISSN 0005-9366

Tourlomousis, P.; Eckersall, P. D., Waterston, M. \& Buncic, S. (2004). A comparison of acute phase protein measurements and meat inspection findings in cattle. Foodbourne Pathogens and Disease, Vol. 1, No. 4, (Winter 2004), pp. 281-290, ISSN 1535-3141 
Tvarijonaviciute, A.; Martínez-Subiela, S., Carrillo-Sánchez, J., Tecles, F., Cerón J.J. (2011). Effects of Orchidectomy in Selective Biochemical Analytes in Beagle Dogs. Reproduction in Domestic Animals (March 2011), doi: 10.1111/j.14390531.2011.01765.x, ISSN 0936-6768

Ulutaş, P.A. \& Ozpinar, A. (2006). Effect of Mannheimia (Pasteurella) haemolytica infection on acute-phase proteins and some mineral levels in colostrum-breast milk-fed or colostrum-breast milk-deprived sheep. Veterinary Research Communications, Vol. 30, No. 5, (July 2006), pp. 485-495, ISSN 0165-7380

Ulutaş, P.A.; Voyvoda, H., Ulutaş, B. \& Aypak, S. (2008). Haptoglobin, serum amyloid A and ceruloplasmin concentrations in goats with mixed helminth infection. Turkiye Parazitol Derg Vol. 32, No. 3, pp. 229-233, ISSN 1300-6320

Van Gucht, S.; Van Reeth, K., Nauwynck, H. \& Pensaert, M. (2005). Porcine reproductive and respiratory syndrome virus infection increases CD14 expression and lipopolysaccharide-binding protein in the lungs of pigs. Viral Immunology Vol. 18, No. 1, pp. 116-126, ISSN 0882-8245

Vandenplas, M.L.; Moore, J.N., Barton, M.H., Roussel, A.J. \& Cohen, N.D. (2005). Concentrations of serum amyloid $\mathrm{A}$ and lipopolysaccharide-binding protein in horses with colic. American Journal of Veterinary Research, Vol. 66, No. 9, (September 2005), pp. 1509-1516, ISSN 0891-6640

Von Borell, E., (1995). Neuroendocrine integration of stress and significance of stress for the performance of farm animals. Applied Animal Behaviour Science Vol. 44, pp. 219-227, ISSN 0168-1591

Wallgren, P.; Brunborg, I.M., Blomqvist, G., Bergström, G., Wikström, F., Allan, G., Fossum, C. \& Jonassen, C.M. (2009). The index herd with PMWS in Sweden: presence of serum amyloid A, circovirus 2 viral load and antibody levels in healthy and PMWS-affected pigs. Acta Veterinaria Scandinavica, Vol. 51, No. 13, doi:10.1186/1751-0147-51-13, (March 2007), ISSN 0044-605X

Warris, P.D. (1998). Choosing appropriate space allowance for slaughter pigs transported by road: a review. The Veterinary Record Vol. 142, No. 17, (April 1998), pp. 449-454, ISSN 0042-4900

Warris, P.D. (2003). Optimal lairage times and conditions for slaughter pigs: a review. The Veterinary Record Vol. 153, No. 6, (August 2003), pp. 170-176, ISSN 2042-7670

Weber, T.E.; Ziemer, C.J. \& Kerr, B.J. (2008). Effects of adding fibrous feedstuffs to the diet of young pigs on growth performance, intestinal cytokines, and circulating acutephase proteins. Journal of Animal Science Vol. 86, No. 4, (April 2008), pp. 871-881, ISSN 1523-3163

Wenz, J.R.; Fox, L.K., Muller, F.J., Rinaldi, M., Zeng, R. \& Bannerman, D.D. (2010). Factors associated with concentrations of select cytokine and acute phase proteins in dairy cows with naturally occurring clinical mastitis. Journal of Dairy Science, Vol. 93, No. 6, (June 2010), pp. 2458-2470, ISSN 0022-0302

Winter, P., Miny, M., Fuchs, K. \& Baumgartner, W. (2006). The potential of measuring serum amyloid A in individual ewe milk and in farm bulk milk for monitoring udder health on sheep dairy farms. Research in Veterinary Science Vol. 81, No. 3, (December 2006), pp. 321-326, ISSN 0034-5288 
Winter, P.; Fuchs, K., Walshe, K. \& Colditz, I.G. (2003). Serum amyloid A in the serum and milk of ewes with mastitis induced experimentally with Staphylococcus epidermidis. Veterinary Record Vol. 152, No. 18, (May 2003), pp. 558-562, ISSN 2042-7670

Yamamoto, S.; Shida, T., Honda, M., Ashida, Y., Rikihisa, Y., Odakura, M., Hayashi, S., Nomura, M. \& Isayama, Y. (1994). Serum C-reactive protein and immune responses in dogs inoculated with Bordetella bronchiseptica (phase I cells). Veterinary Research Communications Vol. 18, No. 5, pp. 347-357, ISSN 0165-7380

Yamamoto, S.; Shida, T., Okimura, T., Otabe, K., Honda, M., Ashida, Y., Furukawa, E., Sarikaputi, M. \& Naiki, M. (1994). Determination of C-reactive protein in serum and plasma from healthy dogs and dogs with pneumonia by ELISA and slide reversed passive latex agglutination test. The Veterinary Quarterly Vol. 16, No. 2, (July 1994), pp. 74-77, ISSN 0165-2176

Yuki, M.; Machida, N., Sawano, T. \& Itoh, H. (2011). Investigation of serum concentrations and immunohistochemical localization of a1-acid glycoprotein in tumor dogs. Veterinary Research Communications, Vol. 35, No. 1, (January 2011), pp. 1-11, ISSN 0165-7380

Yule, T.D.; Roth, M.B., Dreier, K., Johnson, A.F., Palmer-Densmore, M., Simmons, K. \& Fanton, R. (1997). Canine parvovirus vaccine elicits protection from the inflammatory and clinical consequences of the disease. Vaccine, Vol. 15, No. 6-7, (April-May 1997), pp. 720-729, ISSN 0264-410X 
ACUTE PHASE PROTEINS AS EARIY NON-SPECIFIC BIOMARKERS OF HUMAN ANO VETERINARY DISEASES

Edited by Francheo Vees

\section{Acute Phase Proteins as Early Non-Specific Biomarkers of Human and Veterinary Diseases}

Edited by Prof. Francisco Veas

\section{ISBN 978-953-307-873-1}

Hard cover, 408 pages

Publisher InTech

Published online 10, October, 2011

Published in print edition October, 2011

The two volumes of Acute Phase Proteins book consist of chapters that give a large panel of fundamental and applied knowledge on one of the major elements of the inflammatory process during the acute phase response, i.e., the acute phase proteins expression and functions that regulate homeostasis. We have organized this book in two volumes - the first volume, mainly containing chapters on structure, biology and functions of APP, the second volume discussing different uses of APP as diagnostic tools in human and veterinary medicine.

\section{How to reference}

In order to correctly reference this scholarly work, feel free to copy and paste the following:

Jaime Gómez-Laguna, Francisco J. Salguero, Francisco J. Pallarés, Irene M. Rodríguez-Gómez, Inmaculada Barranco and Librado Carrasco (2011). Acute Phase Proteins as Biomarkers in Animal Health and Welfare, Acute Phase Proteins as Early Non-Specific Biomarkers of Human and Veterinary Diseases, Prof. Francisco Veas (Ed.), ISBN: 978-953-307-873-1, InTech, Available from: http://www.intechopen.com/books/acute-phaseproteins-as-early-non-specific-biomarkers-of-human-and-veterinary-diseases/acute-phase-proteins-asbiomarkers-in-animal-health-and-welfare

\section{INTECH}

open science | open minds

\section{InTech Europe}

University Campus STeP Ri Slavka Krautzeka 83/A 51000 Rijeka, Croatia Phone: +385 (51) 770447 Fax: +385 (51) 686166 www.intechopen.com
InTech China

Unit 405, Office Block, Hotel Equatorial Shanghai No.65, Yan An Road (West), Shanghai, 200040, China 中国上海市延安西路65号上海国际贵都大饭店办公楼405单元 Phone: +86-21-62489820

Fax: +86-21-62489821 
(C) 2011 The Author(s). Licensee IntechOpen. This is an open access article distributed under the terms of the Creative Commons Attribution 3.0 License, which permits unrestricted use, distribution, and reproduction in any medium, provided the original work is properly cited. 